\title{
Pengolahan Sinbiotik Kultur Campuran yang Berasal dari Kombinasi Bekatul Gandum sebagai Prebiotik dan Jus Kubis Terfermentasi sebagai Probiotik melalui Proses Fermentasi
}

\section{Processing of Mixed Culture Sinbiotics Originating from the Combination of Wheat Pollard as Prebiotics} and Fermented Cabbage Juice as Probiotics through the Fermentation Process

Cahya Setya Utama1* ${ }^{*}$ Zuprizal$^{2}$, Chusnul Hanim² $^{2}$, Wihandoyo ${ }^{2}$

1Laboratorium Teknologi Pakan, Departemen Peternakan, Fakultas Peternakan dan Pertanian, Universitas Diponegoro, Semarang

${ }^{2}$ Fakultas Peternakan, Universitas Gadjah Mada, Yogyakarta

*Korespondensi dengan penulis (cahyasetyautama@gmail.com)

Artikel ini dikirim pada tanggal 21 Maret 2020 dan dinyatakan diterima tanggal 2 Juni 2020. Artikel ini juga dipublikasi secara online melalui

https://ejournal2.undip.ac.id/index.php/jatp. Hak cipta dilindungi undang-undang. Dilarang diperbanyak untuk tujuan komersial.

Diproduksi oleh Indonesian Food Technologists $®(C 2020$

\begin{abstract}
Abstrak
Penelitian ini bertujuan untuk mengkaji kualitas sinbiotik kultur campuran yang berasal dari jus kubis terfermentasi sebagai probiotik yang ditambahkan pada bekatul gandum sebagai prebiotik melalui proses fermentasi. Penelitian ini dilakukan dengan menggunakan rancangan acak lengkap pola faktorial $3 \times 3$ dengan 3 ulangan. Faktor yang digunakan adalah lama pemeraman dan variasi konsentrasi jus kubis. Parameter yang diamati adalah komponen proksimat (kadar air, abu, lemak kasar, protein kasar, serat kasar dan bahan ekstrak tanpa nitrogen (BETN), komponen serat berupa acid detergent fibre atau ADF, neutral detergent fibre (NDF), selulosa, hemiselulosa dan lignin, serta gross energi, glukosa, sukrosa, mannosa, arabinosa, rafinosa, amilum, amilosa, amilopektin dan pati resisten serta profil sinbiotik kultur campuran melalui analisis scanning electron microscope (SEM). Hasil penelitian memperlihatkan adanya peningkatan yang signifikan pada kadar abu, protein kasar, serat kasar $(p<0,05)$ sedangkan pada parameter BETN, ADF, NDF, hemiselulosa, lignin, gross energi, sukrosa, mannosa, arabinosa, rafinosa, amilosa, amilum, amilopektin dan pati resisten terdapat interaksi antar kedua faktor $(p<0,05)$ namun pada parameter glukosa tidak terdapat interaksi antar kedua faktor. Kesimpulan penelitian yaitu sinbiotik kultur campuran terbaik terdapat pada penambahan $40 \%$ jus kubis terfermentasi dengan lama fermentasi 4 hari. Sinbiotik kultur campuran ini dapat digunakan sebagai sumber additive untuk pangan maupun kepentingan lainnya seperti pakan ternak.
\end{abstract}

Kata kunci: sinbiotik, kultur campuran, kubis, probiotik, bekatul gandum, prebiotik

\begin{abstract}
The objective of this study was to examine the quality of mixed culture synbiotics derived from fermented cabbage juice as probiotics which were added to wheat pollard as a prebiotic through the fermentation process. The study used a completely randomized $3 \times 3$ factorial pattern design with 3 replications and the observed factors were duration of incubation and concentrations of applied cabbage juice. Proximate components (water content, ash, crude fat, crude protein, crude fiber and extraction material without nitrogen or BETN), fiber components (acid detergent fiber (ADF), neutral detergent fiber (NDF), cellulose, hemicellulose and lignin), gross energy, glucose, sucrose, mannose, arabinose, raffinose, starch, amylose, amylopectin and resistant starch and mix culture synbiotic profile through scanning electron microscope (SEM) were analyzed. The results showed a significant increase in ash content, crude protein, crude fiber $(p<0.05)$ while in $B E T N, A D F, N D F$ parameters, hemicellulose, lignin, gross energy, sucrose, mannose, arabinose, raffinose, amylose, starch, amylopectin and resistant starch interaction between the two factors $(p<0.05)$. However, in the glucose parameter there was no interaction between the two factors. The conclusion of the research is that the best mixed culture synbiotic is in the addition of $40 \%$ fermented cabbage juice with 4 days fermentation time. This mixed culture synbiotic can be used as an additive source for food and animal feed.
\end{abstract}

Keywords: synbiotic, mix culture, cabbage, probiotics, fermentation, wheat pollard, prebiotics

\section{Pendahuluan}

Pangan fungsional sekarang ini menjadi tren dikalangan masyarakat luas. Pangan fungsional telah terbukti mengubah, memodifikasi, dan mengembalikan flora usus yang sudah ada sebelumnya (Pandey et al., 2015). Salah satu pangan fungsional yang berkembang adalah sinbiotik. Kombinasi probiotik dan prebiotik berguna untuk meningkatkan daya hidup bakteri probiotik dan kolonisasi mikrobiota di saluran pencernaan. Efek stimulasi prebiotik dengan bakteri exogenous (probiotik) dan endogenous sangat mempengaruhi pertumbuhan dan aktivitas inangnya (Hardy et al., 2013). Sinbiotik dapat meningkatkan daya tahan tubuh dan komposisi mikrobia yang menguntungkan (Markowiak and Sli'zewska, 2017). Hal ini terjadi dikarenakan prebiotik merupakan substrat/nutrien bagi probiotik yang dapat diproses secara fermentasi dan mampu menstimulus antibodi 
alami atau sebagai imunomodulator (Abdel-Raheem et al., 2012). Pemberian sinbiotik sangat efektif dalam meningkatkan pertumbuhan tubuh inang (Mookiah et al., 2014).

Abdel-Raheem et al., (2012) menyatakan bahwa pemberian sinbiotik pada hewan percobaan (ayam broiler) mampu meningkatkan bobot akhir dan berat karkas dibandingkan dengan pemberian prebiotik dan probiotik secara terpisah. Pangan bersinbiotik mampu meningkatkan populasi Lactobacillus $s p$ di dalam duodenum dan jejunum dibanding pemberian probiotik maupun prebiotik secara terpisah (Murarolli et al., 2014). Pemberian sinbiotik juga menurunkan populasi bakteri E. coli pada usus halus dan sekum. Pemberian sinbiotik memberikan pengaruh positif pada tinggi vili dibandingkan dengan pemberian tanpa probiotik dan prebiotik maupun pemberian probiotik dan prebiotik secara terpisah (Alloui et al., 2013). Bengmark (2001) menyatakan bahwa sinbiotik merupakan produk fermentasi yang berasal dari peningkatan kemampuan bakteri probiotik yang disebabkan oleh tersedianya substrat spesifik (prebiotik) untuk melakukan fermentasi. Contoh sinbiotik adalah fructose oligosacarida (FOS) dan Bifidobacteria, laktitol dan Lactobacilli (Collins and Gibson, 1999). Bailey et al. (1991) menggunakan kombinasi FOS dan bakteri probiotik untuk mengurangi kolonisasi Salmonella. Kombinasi ini lebih efektif dalam mengurangi kolonisasi Salmonella daripada pemberian FOS atau probiotik secara terpisah dan dapat digunakan sebagai pengganti pengobatan menggunakan aureomycin (Li et al., 2008).

Kebaharuan dari penelitian ini adalah ditemukannya sumber sinbiotik kultur campuran yang berbahan dasar kubis dan bekatul gandum sebagai sumber probiotik dan prebiotik. Sinbiotik kultur campuran ini nantinya dapat digunakan sebagai supplemen pangan maupun pakan ternak mengingat bahan bakunya berasal dari produk pangan, yaitu kubis dan bekatul gandum. Kubis yang difermentasi digunakan sebagai sumber probiotik dikarenakan mengandung mikroorganisme probiotik yaitu Lactobacillus plantarum, Lactobacillus brevis, Saccharomyces cerevise dan Rhizopus oryzae (Utama et al., 2018a), sedangkan bekatul gandum digunakan sebagai sumber prebiotik dikarenakan banyak mengandung komponen serat pangan seperti arabinosa, mannosa, rafinosa dan pati resisten (Utama et al., 2019). Masih sedikit penelitian yang berkaitan dengan hal ini, oleh karena itu penelitian ini sangat berguna untuk memberikan informasi produk sinbiotik yang mudah dan murah melalui teknologi fermentasi dari bahan baku yang mudah didapat, sehingga dapat diaplikasikan oleh masyarakat yang menginginkan sumber supplemen sehat untuk menjaga kesehatan.

\section{Materi dan Metode \\ Materi}

Bahan penelitian adalah kubis, bekatul gandum (Sriboga Raturaya, Semarang), aquades, kertas saring, kertas saring Whatman 41 (China), $\mathrm{H}_{2} \mathrm{SO}_{4} 0,3 \mathrm{~N}, \mathrm{NaOH}$ $1,5 \mathrm{~N}$, aceton, selenium, $\mathrm{H}_{3} \mathrm{BO}_{3} 4 \%$, Indikator Methylene
Blue - Methyl Red, $\mathrm{NaOH} 45 \%, \mathrm{HCl} 0,1 \mathrm{~N}, \mathrm{H}_{2} \mathrm{SO}_{4}$ teknis, $\mathrm{Na}_{2} \mathrm{EDTA}, \mathrm{Na}_{2} \mathrm{~B}_{4} \mathrm{O}_{7}$, Na-Lauryl Sulfat, Etanol, $\mathrm{Na}_{2} \mathrm{HPO}_{4}$, $\mathrm{Na}_{2} \mathrm{SO}_{4}$, cetyl trimetyl amonium bromida (CTAB), enzim alfa amilase, buffer phosphat $0,1 \mathrm{M}$, enzim pepsin $1 \%$, enzim beta amilase, amilosa murni, asam asetat $1 \mathrm{~N}$ dan alkohol $10 \%$. Alat yang digunakan adalah autoclave (75X All American, US), timbangan analitis (Ohaus, USA), oven (FD23, Germany), eksikator (Schott Duran, Germany), cawan porselin, pinset, tanur (FD1500M Thermo Fisher Scientific Inc., US), labu penyari (Schott Duran, Germany), soxhlet (Schott Duran, Germany), water bath (WNB 29 Memmert GmbH+Co.KG, Germany), labu destruksi (Schott Duran, Germany), beaker glass, gelas ukur, erlenmeyer, kompor listrik, kompor gas, buret, pompa vakum (15601 Robinair, USA), krusibel, bom kalorimeter (1341 Parr Instrument Company, USA), spektrofotometer (UV-mini 1240 Shimadzu, Japan) dan scanning electron microscope (JSM-6510LA Jeol Ltd., Japan).

\section{Metode}

Penelitian diawali dengan pembuatan probiotik dari jus kubis terfermentasi (Utama et al., 2018a) dan pembuatan prebiotik dari bekatul gandum (Utama et al., 2019). Bekatul gandum prebiotik mempunyai kadar air $45 \%$ sehingga perlu ditambahkan air sampai dengan kadar air $70 \%$. Adapun rumus penambahan air menurut Utama et al., (2017) adalah kadar air bahan dikalikan berat bahan lalu ditambah dengan berat bahan yang kemudian dibagi dengan jumlah berat bahan dan air yang ditambahkan yang kemudian dikalikan 100 .

Penambahan jus kubis terfermentasi sebesar 20 dan $40 \%$ dihitung berdasarkan jumlah air yang ditambahkan sampai memenuhi kadar air 70\%. Fermentasi dilakukan selama 2, 3 dan 4 hari. Proses fermentasi dilakukan pada suhu ruang dan anaerob fakultatif. Bekatul gandum terfermentasi kemudian dipanen dan dikeringkan dalam pengering terkendali pada suhu $40^{\circ} \mathrm{C}$ selama \pm 72 jam, setelah itu dihaluskan dan siap untuk dianalisis sesuai parameter uji.

Penelitian ini menggunakan rancangan acak lengkap pola faktorial $3 \times 3$ dengan 3 ulangan. Faktor pertama adalah konsentrasi jus kubis 0, 20 dan 40\%, sedangkan faktor kedua adalah lama pemeraman 2, 3 dan 4 hari. Parameter yang diamati yaitu komponen proksimat, komponen serat Acid Detergent Fibre (ADF), Neutral Detergent Fibre (NDF), selulosa, hemiselulosa dan lignin), gross energi, kandungan monosacharida (mannosa, arabinosa, glukosa dan sukrosa), Komponen oligosacharida (rafinosa), komponen pati (amilosa, amilum, amilopektin dan pati resisten) juga dianalisis. Profil serat bekatul gandum sinbiotik dianalisis melalui scanning electron microscope (SEM).

\section{Pengujian Parameter}

Pengukuran komponen proksimat meliputi analisis kadar air, abu, lemak kasar, protein kasar dan serat kasar dilakukan dengan menggunakan prosedur AOAC (2006). Pengukuran serat meliputi kadar ADF, NDF, hemiselulosa, selulosa dan lignin dilakukan dengan menggunakan metode Goering and Van Soest 
(1970). Pengukuran gross energi dilakukan dengan menggunakan bomb kalorimeter sesuai dengan prosedur dari AOAC (2006).

\section{Analisis Kandungan Karbohidrat dengan HPLC}

Sampel sebanyak 0,2 g dimasukkan ke dalam botol vial yang kemudian ditambahkan $5 \mathrm{ml}$ alkohol $80 \%$ lalu digojok selama 1 menit. Setelah penyaringan dengan Whatman no. 4, larutan kemudian dipekatkan dengan rotavapor lalu diambil $3 \mathrm{ml}$ larutan untuk dilarutkan dengan aquabides dan dilakukan sentrifugasi. Setelah itu disaring dengan kertas saring Millipore yang kemudian ditampung pada tabung Eppendorf yang siap diinjeksikan ke HPLC (Sudarmadji et al., 1984).

\section{Analisis Kadar Amilum}

Sebanyak $5 \mathrm{~g}$ sampel dimasukkan dalam gelas piala $250 \mathrm{ml}$ dan tambahkan $50 \mathrm{ml}$ aquades yang kemudian aduk selama 1 jam. Suspensi disaring dengan kertas saring Whatman 42 dan dicuci dengan aquades sampai volume filtrat $250 \mathrm{ml}$. Hasil saringan kemudian dipindahkan ke dalam erlenmeyer dengan pencucian

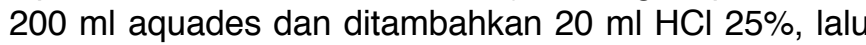
ditutup dengan pendingin terbalik dan dipanaskan diatas penangas air mendidih selama 2,5 jam. Setelah dingin dinetralkan dengan larutan $\mathrm{NaOH} 45 \%$ yang kemudian diencerkan sampai volume $500 \mathrm{ml}$, kemudian disaring dengan kertas saring Whatman 42. Kadar gula ditentukan sebagai glukosa dari filtrat yang diperoleh. Berat glukosa kemudian dikalikan 0,9 yang merupakan berat pati (Sudarmadji et al., 1984).

\section{Analisis Kadar Amilosa dan Amilopektin}

Sebanyak 100 mg sampel dimasukkan ke dalam tabung reaksi yang kemudian ditambahkan $1 \mathrm{ml}$ etanol $95 \%$ dan $9 \mathrm{ml} \mathrm{NaOH} 1 \mathrm{~N}$. Pemanasan dalam air mendidih dilakukan selama 10 menit sampai akhirnya terbentuk gel. Pindahkan seluruh gel kedalam labu takar $100 \mathrm{ml}$. Sebanyak $5 \mathrm{ml}$ dari larutan tersebut kemudian masukkan ke dalam labu takar $100 \mathrm{ml}$ dan ditambahkan $1 \mathrm{ml}$ asam asetat $1 \mathrm{~N}$ dan $2 \mathrm{ml}$ larutan lod yang kemudian dikocok dan diamkan selama 20 menit. Intensitas warna diukur dengan spektrofotometer pada panjang gelombang $625 \mathrm{~nm}$ dan kadar amilosanya dapat untuk dihitung (Sudarmadji et al., 1984). Berdasarkan pada metode tersebut maka amilopektin juga dapat ditentukan dengan melakukan perhitungan dari kadar amilum dikurangi kadar amilosa.

\section{Analisis Pati Resisten}

Pati resisten diukur dengan menggunakan metode multienzim. Sebanyak 0,5 g sampel dimasukkan dalam gelas erlenmeyer, kemudian ditambahkan $25 \mathrm{ml}$ larutan buffer phospat $0,1 \mathrm{M} \mathrm{pH} 7$ yang kemudian diaduk sampai terbentuk suspensi. Kemudian kedalam larutan tersebut ditambahkan 0,1 $\mathrm{ml}$ enzim aplhaamilase ke dalam erlenmeyer yang telah berisi sampel. Erlenmeyer kemudian ditutup dengan alumunium foil dan diinkubasi dalam penangas air bersuhu $100^{\circ} \mathrm{C}$ selama 15 menit sambil diaduk. Sampel kemudian didinginkan dan ditambahkan $20 \mathrm{ml}$ air destilasi plus $5 \mathrm{ml} \mathrm{HCl} 1 \mathrm{~N}$.
Selanjutnya ditambahkan $1 \mathrm{ml}$ enzim pepsin $1 \% \mathrm{ke}$ dalam erlenmeyer tersebut dan dilanjutkan dengan inkubasi pada suhu $40^{\circ} \mathrm{C}$ selama 1 jam. Erlenmeyer kemudian ditambahkan $20 \mathrm{ml}$ air destilasi, $5 \mathrm{ml} \mathrm{NaOH} 1$ $\mathrm{N}$, dan enzim beta amilase sebanyak $0,1 \mathrm{ml}$ yang kemudian ditutup dan diinkubasi kembali dalam penangas air bergoyang bersuhu $40^{\circ} \mathrm{C}$ selama 1 jam. Setelah dilakukan penyaringan, residu kemudian dilarutkan dan dianalisis kadar patinya (Sudarmadji et al., 1984).

\section{Analisis Morfologi}

Analisis morfologi produk dilakukan dengan menggunakan SEM sesuai dengan manual prosedur yang telah ditentukan dari pembuat alatnya (JSM6510LA Jeol Ltd., Japan)

\section{Analisis Data}

Data pengukuran parameter profil kultur campuran diukur dengan SEM dianalisis secara deskripsi, sedangkan data pengaruh lama fermentasi yaitu komposisi kimia (proksimat), komponen serat (ADF, NDF, selulosa, hemiselulosa dan lignin), gross energi, mannosa, arabinosa, glukosa dan sukrosa, komponen oligosakarida (rafinosa) dan komponen pati (amilosa, amilum, amilopektin dan pati resisten) dianalisis variansinya dari rancangan acak lengkap pola faktorial 3x3 dengan 3 ulangan dan uji lanjut dilakukan jika hasilnya berpengaruh nyata dengan menggunakan analisis Duncan's Multiple Range Test (Steel dan Torrie, 1993).

\section{Hasil dan Pembahasan}

Komponen proksimat

Hasil analisis statistik menunjukkan tidak ada pengaruh perlakuan pada pengolahan sinbiotik kultur campuran yang berasal dari kombinasi bekatul gandum sebagai prebiotik dan jus kubis terfermentasi sebagai probiotik melalui proses fermentasi pada parameter kadar air. Faktor lama peram tidak mengakibatkan perubahan kadar air. Hal ini dikarenakan kadar air yang digunakan dalam fermentasi pada semua perlakuan sama yaitu sebesar $70 \%$. Kadar air $70 \%$ merupakan hasil terbaik dari pre-penelitian yang telah dilakukan dan telah sesuai dengan media hidup mikroorganisme yang akan ditumbuhkan. Wigyanto et al. (2001) menyatakan bahwa produk fermentasi dari bakteri asam laktat maupun Saccharomyces cerevisiae akan memfermentasi gula menjadi asam organik dengan hasil metabolit sekunder berupa $\mathrm{CO}_{2}$ dan $\mathrm{H}_{2} \mathrm{O}$. Faktor penambahan jus kubis terfermentasi tidak mempengaruhi kadar air substrat hasil fermentasi. Perubahan kadar air selama fermentasi (Tabel 1) disebabkan oleh proses perombakan substrat yang dilakukan oleh mikroorganisme didalam jus kubis terfermentasi. Mikroorganisme yang berasal dari jus kubis terfermentasi terdiri atas Lactobacillus plantarum, Lactobacillus brevis, Rhizopus oryzae dan Saccharomyces cerevisiae. Lewthwaite et al. (1997) menyatakan bahwa bakteri asam laktat dalam medium akan memfermentasi atau menghidrolisis gula menjadi 
asam laktat, asam organik, $\mathrm{CO}_{2}, \mathrm{H}_{2} \mathrm{O}$ dan energi untuk digunakan sebagai mensintesis sel sehingga terjadi kenaikan jumlah sel. Interaksi antara faktor lama peram dan penambahan jus kubis terfermentasi tidak mempengaruhi parameter kadar air. Hal ini dikarenakan kadar air dan penambahan jus kubis terfermentasi sudah dihitung dengan hasil yang sama yaitu kadar air $70 \%$, selain itu proses fermentasi dilakukan dalam kondisi anaerob fakultatif sehingga faktor lingkungan tidak memberikan dampak pada penambahan kadar air. Perubahan kadar air dari 70 menjadi $77 \%$ (Tabel 1) diakibatkan oleh proses fermentasi bekatul gandum dengan mikroorganisme yang berada pada jus kubis terfermentasi sehingga menghasilkan metabolit sekunder berupa $\mathrm{CO}_{2}$ dan $\mathrm{H}_{2} \mathrm{O}$. Rackis (1989) menyatakan bahwa perombakan karbohidrat oleh mikroorganisme menghasilkan gas-gas flatus seperti $\mathrm{H}_{2}$ dan $\mathrm{CO}_{2}$ serta $\mathrm{H}_{2} \mathrm{O}$.

Tabel 1. Komponen proksimat sinbiotik kultur campuran yang berasal dari kombinasi bekatul gandum sebagai prebiotik dan jus kubis terfermentasi sebagai probiotik melalui proses fermentasi

\begin{tabular}{|c|c|c|c|c|c|}
\hline \multirow[t]{2}{*}{ Parameter } & \multirow{2}{*}{$\begin{array}{l}\text { Lama } \\
\text { Peram } \\
\text { (Hari) }\end{array}$} & \multicolumn{3}{|c|}{$\begin{array}{c}\text { Penambahan Jus Kubis Terfermentasi } \\
(\%)\end{array}$} & \multirow[t]{2}{*}{ Rerata } \\
\hline & & 0 & 20 & 40 & \\
\hline $\begin{array}{l}\text { Kadar Air } \\
(\%)\end{array}$ & $\begin{array}{r}2 \\
3 \\
4 \\
\text { Rerata } \\
\end{array}$ & $\begin{array}{l}77,77 \pm 0,12 \\
77,46 \pm 0,13 \\
77,56 \pm 0,14 \\
77,60 \pm 0,13 \\
\end{array}$ & $\begin{array}{l}77,52 \pm 0,09 \\
77,57 \pm 0,04 \\
77,47 \pm 0,07 \\
77,51 \pm 0,07 \\
\end{array}$ & $\begin{array}{l}77,53 \pm 0,20 \\
77,52 \pm 0,17 \\
77,58 \pm 0,18 \\
77,54 \pm 0,18\end{array}$ & $\begin{array}{l}77,61 \pm 0,14 \\
77,52 \pm 0,11 \\
77,54 \pm 0,13 \\
\end{array}$ \\
\hline $\begin{array}{l}\text { Kadar Abu } \\
(\% \text { BK })\end{array}$ & $\begin{array}{c}2 \\
3 \\
4 \\
\text { Rerata }\end{array}$ & $\begin{array}{r}4,87 \pm 0,11 \\
5,19 \pm 0,16 \\
5,88 \pm 0,43 \\
5,32^{\mathrm{c}} \pm 0,23\end{array}$ & $\begin{array}{r}6,09 \pm 0,29 \\
6,31 \pm 0,35 \\
6,49 \pm 0,77 \\
6,30^{\mathrm{b}} \pm 0,47\end{array}$ & $\begin{array}{r}7,61 \pm 0,28 \\
7,53 \pm 0,14 \\
7,60 \pm 0,45 \\
7,58^{a} \pm 0,29\end{array}$ & $\begin{array}{r}6,15^{\mathrm{b}} \pm 0,23 \\
6,36^{\mathrm{ab}} \pm 0,21 \\
6,66^{\mathrm{a}} \pm 0,55 \\
\end{array}$ \\
\hline $\begin{array}{l}\text { Kadar } \\
\text { Lemak } \\
(\% \text { BK) }\end{array}$ & $\begin{array}{c}2 \\
3 \\
4 \\
\text { Rerata } \\
\end{array}$ & $\begin{array}{l}0,03 \pm 0,01 \\
0,03 \pm 0,02 \\
0,04 \pm 0,01 \\
0,03 \pm 0,01\end{array}$ & $\begin{array}{l}0,02 \pm 0,01 \\
0,03 \pm 0,01 \\
0,02 \pm 0,01 \\
0,03 \pm 0,01\end{array}$ & $\begin{array}{l}0,02 \pm 0,01 \\
0,03 \pm 0,01 \\
0,03 \pm 0,01 \\
0,03 \pm 0,01\end{array}$ & $\begin{array}{l}0,03 \pm 0,01 \\
0,03 \pm 0,01 \\
0,03 \pm 0,01 \\
\end{array}$ \\
\hline $\begin{array}{l}\text { Protein } \\
\text { Kasar } \\
(\% \text { BK) }\end{array}$ & $\begin{array}{c}2 \\
3 \\
4 \\
\text { Rerata }\end{array}$ & $\begin{array}{r}14,46 \pm 0,35 \\
14,75 \pm 0,56 \\
16,13 \pm 0,12 \\
15,12^{\mathrm{a}} \pm 0,34\end{array}$ & $\begin{array}{r}14,83 \pm 0,18 \\
14,65 \pm 0,06 \\
14,50 \pm 0,74 \\
14,66^{\mathrm{ab}} \pm 0,33\end{array}$ & $\begin{array}{r}13,91 \pm 1,15 \\
14,55 \pm 0,79 \\
14,89 \pm 0,54 \\
14,45^{\mathrm{b}} \pm 0,83\end{array}$ & $\begin{array}{r}14,40^{\mathrm{b}} \pm 0,56 \\
14,65^{\mathrm{ab}} \pm 0,47 \\
15,17^{\mathrm{a}} \pm 0,47 \\
\end{array}$ \\
\hline $\begin{array}{l}\text { Serat } \\
\text { Kasar } \\
(\% \text { BK) }\end{array}$ & $\begin{array}{c}2 \\
3 \\
4 \\
\text { Rerata }\end{array}$ & $\begin{array}{r}5,92 \pm 1,43 \\
8,26 \pm 0,80 \\
10,05 \pm 0,81 \\
8,08 \mathrm{a} \pm 1,01\end{array}$ & $\begin{array}{r}6,11 \pm 0,54 \\
6,32 \pm 1,69 \\
7,54 \pm 0,92 \\
6,65^{\mathrm{b}} \pm 1,05\end{array}$ & $\begin{array}{r}6,56 \pm 0,36 \\
8,21 \pm 0,38 \\
9,59 \pm 0,71 \\
8,11^{a} \pm 0,48\end{array}$ & $\begin{array}{l}6,15^{\mathrm{c}} \pm 0,78 \\
7,60^{\mathrm{b}} \pm 0,96 \\
9,06^{\mathrm{a}} \pm 0,81 \\
\end{array}$ \\
\hline $\begin{array}{l}\text { BETN } \\
(\% \text { BK })\end{array}$ & $\begin{array}{l}2 \\
3 \\
4\end{array}$ & $\begin{array}{r}74,62^{\mathrm{a}} \pm 1,12 \\
71,77^{\mathrm{b}} \pm 0,42 \\
67,89^{\mathrm{d}} \pm 1,25\end{array}$ & $\begin{array}{l}72,95^{a b} \pm 0,20 \\
72,68^{a b} \pm 2,09 \\
71,44^{b c} \pm 1,88\end{array}$ & $\begin{array}{r}71,90^{\mathrm{bc}} \pm 1,01 \\
69,68^{\mathrm{cd}} \pm 1,22 \\
67,90^{\mathrm{d}} \pm 0,89\end{array}$ & $\begin{array}{l}73,16^{a} \pm 0,77 \\
71,38^{b} \pm 1,24 \\
69,08^{c} \pm 1,34\end{array}$ \\
\hline & Rerata & $71,45^{a} \pm 0,93$ & $72,36^{a} \pm 1,39$ & $69,83^{b} \pm 1,04$ & \\
\hline
\end{tabular}

Keterangan: a,b,c Superskrip berbeda pada baris dan kolom yang sama menunjukan perbedaan nyata $(\mathrm{P}<0,05)$.

Pengolahan sinbiotik kultur campuran yang berasal dari kombinasi bekatul gandum sebagai prebiotik dan jus kubis terfermentasi sebagai probiotik melalui proses fermentasi berpengaruh pada peningkatan kadar abu $(p<0,05)$. Faktor lama peram dan penambahan jus kubis terfermentasi meningkatkan kadar abu namun tidak memberikan interaksi antar ke dua faktor tersebut. Kadar abu pada faktor lama peram 4 hari lebih tinggi dibanding lama peram 2 hari. Hal ini disebabkan oleh menurunnya kadar BETN. Penurunan ini disebabkan oleh kinerja mikroorganisme yang berada dalam jus kubis terfermentasi. Selama proses fermentasi, bakteri asam laktat memetabolisme kandungan nutrien yang banyak terdapat pada substrat dan digunakan untuk pertumbuhan sel (Lewthwaite et al., 1997). Kadar abu pada faktor penambahan jus kubis terfermentasi $40 \%$ lebih tinggi dibanding dengan penambahan jus kubis terfermentasi 20 dan $0 \%$. Hal ini dikarenakan semakin banyak jumlah jus kubis terfermentasi yang ditambahkan, kadar abu semakin meningkat. Kadar abu tertinggi pada perlakuan penambahan jus kubis terfermentasi sebanyak $40 \%$ dengan lama peram 2 hari sebesar $7,61 \pm 0,28 \%$ dan terendah pada perlakuan penambahan jus kubis terfermentasi $0 \%$ dengan lama peram 2 hari sebesar $4,75 \pm 0,11 \%$. Peningkatan kadar abu dikarenakan penambahan jus kubis terfermentasi dari 0 menjadi $40 \%$ yang diikuti oleh penurunan kadar protein kasar dan BETN. Wahyu (1994) menyatakan bahwa abu merupakan unsur pembentuk BETN dan berpengaruh 
pada komposisi bahan organik. Kenaikan kadar abu dikarenakan terjadi penurunan bahan organik dari bekatul gandum terfermentasi. Interaksi antara faktor lama peram dan penambahan jus kubis terfermentasi tidak berpengaruh pada parameter kadar abu. Perubahan kadar abu dari 4,87 $\pm 0,11 \%$ menjadi $7,60 \pm 0,45 \%$ disebabkan oleh proses fermentasi bekatul gandum dengan mikroorganisme yang berada pada jus kubis terfermentasi sehingga merombak komponen bahan organik sehingga kadar abu mengalami kenaikan. Wigyanto et al. (2001) menyatakan bahwa proses fermentasi terjadi pemecahan disakarida dan hidrolisa polisakarida menjadi monosakarida atau gula reduksi.

Perlakuan pengolahan sinbiotik kultur campuran yang berasal dari kombinasi bekatul gandum sebagai prebiotik dan jus kubis terfermentasi sebagai probiotik melalui proses fermentasi tidak memberikan pengaruh kadar lemak kasar. Hal ini disebabkan oleh kadar lemak kasar bekatul gandum yang relatif rendah berkisar antara 0,01-0,03\%. Kadar lemak kasar bekatul gandum telah mengalami proses pendahuluan sebelum dilakukan fermentasi. Proses pendahuluan meliputi penambahan air sampai $45 \%$ dan proses pemanasan dengan autoclave pada suhu $121^{\circ} \mathrm{C}$ selama 15 menit serta pengkondisian kadar air sampai $70 \%$. Rerata kadar lemak pada faktor lama peram 2, 3 dan 4 hari berturutturut sebesar $0,03 \pm 0,01 \% ; \quad 0,03 \pm 0,01 \%$ dan $0,03 \pm 0,01 \%$. Lama peram tidak mengubah kandungan kadar lemak. Hal ini disebabkan oleh mikroorganisme didalam jus kubis terfermentasi tidak bersifat merombak lemak (Utama et al., 2019). Butt (1999) menyatakan bahwa sifat penting bakteri asam laktat, yaitu memfermentasi gula dengan menghasilkan sejumlah asam laktat dan tidak mampu menghasilkan enzim katalase. Rerata faktor penambahan jus kubis terfermentasi tidak menunjukkan perbedaan antar perlakuan pada parameter kadar lemak kasar. Penambahan jus kubis terfermentasi tidak merubah kadar lemak. Hal ini disebabkan oleh mikoorganisme yang berasal dari jus kubis terfermentasi tidak mampu merombak lemak. Carr et al. (2002) menyatakan bahwa bakteri asam laktat merupakan bakteri yang tidak mampu memproduksi enzim katalase. Interaksi antara faktor lama peram dan penambahan jus kubis terfermentasi tidak berpengaruh pada parameter kadar lemak kasar. Hal ini dikarenakan pada saat proses fermentasi bekatul gandum dengan mikroorganisme yang berada pada jus kubis terfermentasi tidak dapat merombak kadar lemak. Sembayang (2006) menyatakan bahwa metabolisme karbohidrat oleh bakteri asam laktat memfermentasi glukosa menjadi asam laktat, etanol dan $\mathrm{CO}_{2}$ namun tidak memfermentasi lemak.

Perlakuan pengolahan sinbiotik kultur campuran yang berasal dari kombinasi bekatul gandum sebagai prebiotik dan jus kubis terfermentasi sebagai probiotik melalui proses fermentasi memberikan pengaruh nyata pada perubahan kadar protein kasar $(p<0,05)$. Kadar protein kasar pada faktor lama peram 4 hari lebih tinggi dibanding dengan lama peram 2 hari, namun sama dengan lama peram 3 hari. Hal ini disebabkan oleh menurunnya kadar BETN. Semakin lama fermentasi kadar BETN semakin menurun. Penurunan ini disebabkan oleh kinerja mikroorganisme yang berada dalam jus kubis terfermentasi. Selama proses fermentasi, bakteri asam laktat memetabolisme kandungan nutrien yang banyak terdapat pada substrat dan digunakan untuk pertumbuhan sel (Lewthwaite et al., 1997). Faktor penambahan jus kubis terfermentasi $0 \%$ lebih tinggi dibandingkan dengan penambahan jus kubis terfermentasi $40 \%$. Hal ini dikarenakan semakin banyak jus kubis terfermentasi yang ditambahkan, kadar protein semakin menurun. Jus kubis terfermentasi mengandung Lactobacillus plantarum, Lactobacillus brevis, Rhizopus oryzae dan Saccharomyces cerevise. Penurunan protein yang terjadi dikarenakan dominasi sifat proteolitik dari Lactobacillus dan Rhizopus oryzae sehingga menurunkan kandungan protein (Utama et al., 2018a). Butt (1999) menyatakan bahwa sifat penting bakteri asam laktat, antara lain, bersifat proteolitik, dan memfermentasi gula dengan menghasilkan asam laktat. Khalid and Elmer (2008) mengatakan bahwa Lactobacillus plantarum memiliki kemampuan proteolitik yang lebih baik dibandingkan Lactobacillus casei. Penurunan protein terjadi diduga karena selama fermentasi, terjadi perombakan protein menjadi asam amino dan peptide oleh mikroba sehingga berakibat semakin banyak asam amino dan peptida yang terbentuk (Fardiaz,1992). Interaksi antara faktor lama peram dan penambahan jus kubis terfermentasi tidak mempengaruhi kadar protein kasar. Hal ini dikarenakan pada saat proses fermentasi penambahan jus kubis terfermentasi dan lama peram belum mampu merombak sebagian besar protein yang berada pada bekatul gandum. Bakteri asam laktat memfermentasi glukosa menjadi asam laktat, etanol dan $\mathrm{CO}_{2}$ (Sembayang, 2006).

Perlakuan pengolahan sinbiotik kultur campuran yang berasal dari kombinasi bekatul gandum sebagai prebiotik dan jus kubis terfermentasi sebagai probiotik melalui proses fermentasi memberikan pengaruh nyata pada peningkatan kadar serat kasar $(p<0,05)$. Kadar serat kasar pada faktor lama peram 4 hari lebih tinggi dibanding dengan lama peram 2 dan 3 hari. Semakin lama proses fermentasi, semakin meningkatkan kadar serat kasar bekatul gandum. Hal ini dikarenakan terjadi peningkatan kadar amilosa, amilum dan amilopektin (Tabel 4) yang mempengaruhi peningkatan kadar serat kasar, meskipun kadar hemiselulosa dan lignin cenderung menurun (Tabel 2). Serat kasar sebagian besar berasal dari sel dinding tanaman dan mengandung selulosa, hemiselulosa dan lignin (Cherney, 2000; Lu et al., 2005). Kadar serat kasar pada faktor penambahan jus kubis terfermentasi $0 \%$ lebih tinggi dibanding dengan penambahan jus kubis terfermentasi $20 \%$ namun tidak dengan penambahan jus kubis terfermentasi $40 \%$. Rerata penambahan level jus kubis fermentasi menurunkan serat kasar dari $8,12 \pm 0,48 \%$ menjadi $6,65 \pm 1,05 \%$. Penurunan kadar serat kasar diakibatkan oleh kinerja mikroorganisme pencerna serat yaitu Lactobacillus plantarum, Lactobacillus brevis, Saccharomyces cerevise dan 
Rhizopus oryzae. Baron et al. (1989) menyatakan bahwa Lactobacillus plantarum merupakan bakteri yang memiliki kemampuan sangat baik dalam memfermentasi serat pangan. Penurunan serat pangan sumber prebiotik terlihat pada parameter hemiselulosa, lignin, gross energi, glukosa, sukrosa, arabinosa, mannosa, rafinosa dan pati resisten (Tabel 2, 3 dan 4). Bakteri asam laktat memanfaatkan serat kasar yang dihidrolisis menjadi asam laktat, asam lemak rantai pendek dan energi (Miller and Wollin, 1996). Interaksi antara faktor lama peram dan penambahan jus kubis terfermentasi tidak menunjukkan pengaruh pada perlakuan serat kasar. Hal ini dikarenakan pada saat proses fermentasi penambahan jus kubis afkir terfermentasi dan lama peram belum mampu merombak sebagian serat kasar yang berada pada bekatul gandum meskipun semakin lama pemeraman kadar serat kasar meningkat. Peningkatan serat kasar dikarenakan adanya peningkatan kadar amilosa, amilum dan amilopektin (Tabel 4), meskipun kadar hemiselulosa dan lignin cenderung menurun (Tabel 2). Serat kasar merupakan bagian dari karbohidrat dan didefinisikan sebagai fraksi yang tersisa setelah didigesti dengan larutan asam sulfat standar dan sodium hidroksida pada kondisi terkondisi (Cherney, 2000).

Perlakuan pengolahan sinbiotik kultur campuran yang berasal dari kombinasi bekatul gandum sebagai prebiotik dan jus kubis terfermentasi sebagai probiotik melalui proses fermentasi memberikan pengaruh pada penurunan kadar BETN $(p<0,05)$. Rerata kandungan BETN pada faktor lama peram mengalami penurunan berturut-turut adalah $73,16 \pm 0,77 \% ; 71,38 \pm 1,24 \%$ dan $69,08 \pm 1,34 \%$ (Tabel 1). Hal ini dikarenakan oleh kinerja Lactobacillus plantarum, Lactobacillus brevis, Rhizopus oryzae dan Saccharomyces cerevise yang menggunakan sumber karbohidrat sebagai nutrien bagi perkembangan mikroorganisme tersebut. Kadar glukosa, sukrosa, arabinosa dan mannosa juga mengalami penurunan (Tabel 3). Bakteri asam laktat dalam medium dapat memfermentasi atau menghidrolisis gula menjadi komponen-komponen yang lebih sederhana menjadi asam laktat, asam organik, $\mathrm{CO}_{2}, \mathrm{H}_{2} \mathrm{O}$ dan energi (Lewthwaite et al., 1997). Kadar BETN pada faktor penambahan jus kubis terfermentasi $40 \%$ lebih rendah dibandingkan dengan penambahan jus kubis terfermentasi 20 dan $0 \%$ namun penambahan jus kubis terfermentasi 0 dan $20 \%$ mempunyai kandungan BETN yang sama. Hal ini terjadi karena proses perombakan nutrien pada bekatul gandum yang dilakukan oleh mikroorganisme yang ada pada jus kubis fermentasi. Penurunan kadar BETN diakibatkan oleh kinerja Lactobacillus plantarum, Lactobacillus brevis, Rhizopus oryzae dan Saccharomyces cerevise yang menggunakan sumber karbohidrat sebagai nutrien bagi perkembangan mikroorganisme tersebut. Ryan et al. (2006) menyebutkan bahwa Lactobacillus plantarum memiliki aktivitas amilolitik yang lebih besar, sehingga mampu menghidrolisis pati menjadi komponen yang lebih sederhana dan memanfaatkannya sebagai sumber nutrien bagi pertumbuhannya. Salminen and Wright (1993) menyatakan bahwa Lactobacillus plantarum memiliki daya amilolitik yang baik dan dapat memproduksi maltosa, maltotriosa dan sejumlah kecil glukosa dari amilopektin. Interaksi antara faktor lama peram dan penambahan jus kubis terfermentasi terjadi penurunan yang signifikan terhadap parameter BETN. Interaksi ini menandakan bahwa kinerja bakteri asal jus kubis terfermentasi sangat optimal dan mampu berperan sebagai sinbiotik. Hal ini terlihat dari penurunan kadar rafinosa dan pati resisten yang merupakan cerminan dari prebiotik (Tabel 4). Penurunan tersebut diduga disebabkan oleh kinerja enzim yang dihasilkan oleh Lactobacillus plantarum yang mampu memecah senyawa kompleks menjadi senyawa yang lebih sederhana sehingga dapat dimanfaatkan untuk metabolisme sel (Giraud and Williams, 2000; Charalampopoulos, et al., 2002).

\section{Analisis Kandungan Serat}

Perlakuan pengolahan sinbiotik kultur campuran yang berasal dari kombinasi bekatul gandum sebagai prebiotik dan jus kubis terfermentasi sebagai probiotik melalui proses fermentasi memberikan pengaruh pada peningkatan kadar ADF $(p<0,05)$. Rerata kandungan ADF pada faktor lama peram mengalami peningkatan berturut-turut adalah 0,07 $\pm 0,02 ; \quad 0,16 \pm 0,02$ dan $0,12 \pm 0,02 \%$. Hal ini disebabkan oleh meningkatnya kadar lignin bekatul gandum terfermentasi. Selulosa dan lignin merupakan komponen penyusun dari ADF (NRC, 2001). Rerata kandungan ADF pada faktor penambahan jus kubis terfermentasi mengalami penurunan yaitu $0,12 \pm 0,02 \% ; 0,14 \pm 0,01 \%$ dan $0,09 \pm 0,02 \%$ (Tabel 2 ). Penurunan tersebut juga diikuti oleh penurunan gross energi, glukosa dan sukrosa (Tabel 3). Jung (1997) menyatakan bahwa kandungan ADF dapat digunakan untuk menduga besaran energi pada bahan pakan berserat. Interaksi antara faktor lama peram dan penambahan jus kubis terfermentasi terjadi peningkatan pada parameter ADF. Peningkatan ini diduga disebabkan oleh meningkatnya kadar amilosa, amilum dan amilopektin bekatul gandum terfermentasi (Tabel 4). Marsono (1998) dan Sajilata et al. (2006) menyatakan bahwa pati yang tergelatinisasi dapat membentuk struktur pasta pati, yang menyebabkan pembentukan jaringan tiga dimensi pada seluruh volume gel yang terbentuk akibat terjerapnya air didalam gel. Fenomena ini mengakibatkan perubahan struktur serat yang terkandung didalam bekatul gandum, sehingga mempengaruhi kandungan ADF.

Perlakuan pengolahan sinbiotik kultur campuran yang berasal dari kombinasi bekatul gandum sebagai prebiotik dan jus kubis terfermentasi sebagai probiotik melalui proses fermentasi memberikan pengaruh pada penurunan kadar NDF $(p<0,05)$. Rerata kandungan NDF pada faktor lama peram tidak memperlihatkan perubahan pada kadar NDF. Hal ini dikarenakan konsentrasi NDF dalam pakan memiliki korelasi negatif dengan konsentrasi energi (Tabel 3). Pakan atau ransum yang memiliki kandungan NDF yang sama belum tentu memiliki jumlah energi yang sama, untuk itu bahan pakan atau ransum yang memiliki konsentrasi NDF yang lebih tinggi kemungkinan memiliki jumlah 
energi yang lebih tinggi dibandingkan dengan pakan atau ransum yang memiliki kandungan NDF yang lebih rendah (NRC, 2001). Rerata faktor penambahan jus kubis terfermentasi memperlihatkan penurunan pada parameter NDF. Penurunan nilai neutral detergent fibre pada faktor penambahan jus kubis terfermentasi disebabkan meningkatnya kadar lignin yang mengakibatkan menurunnya kadar hemiselulosa (Tabel 2). NDF mengambarkan semua komponen karbohidrat struktural dalam dinding sel tanaman yang meliputi selulosa, hemiselulosa dan lignin. NDF merupakan metoda yang terbaik untuk memisahkan antara karbohidrat struktural dengan karbohidrat non-struktural pada tumbuhan. Proporsi dari komponen-komponen penyusun NDF (hemiselulosa, selulosa dan lignin) akan mempengaruhi nilai kecernaan dari NDF (NRC, 2001). Interaksi antara faktor lama peram dan penambahan jus kubis terfermentasi mengakibatkan penurunan pada parameter NDF. Penurunan ini disebabkan oleh kinerja mikroorganisme yang berasal dari jus kubis terfermentasi yang mampu mencerna sumber serat. Hal ini terlihat dari menurunnya kadar hemiselulosa (Tabel 2), meningkatnya kadar arabinosa dan manosa (Tabel 3). Crampton and Haris (1969) menyatakan bahwa penurunan kadar NDF disebabkan oleh menurunnya kadar hemiselulosa dan meningkatnya kadar lignin.

Tabel 2. Komponen serat sinbiotik kultur campuran yang berasal dari kombinasi bekatul gandum sebagai prebiotik dan jus kubis terfermentasi sebagai probiotik melalui proses fermentasi

\begin{tabular}{|c|c|c|c|c|c|}
\hline \multirow{2}{*}{$\begin{array}{l}\text { Parameter } \\
(\% \text { BK) }\end{array}$} & \multirow[t]{2}{*}{ Lama Peram (Hari) } & \multicolumn{3}{|c|}{ Penambahan Jus Kubis Terfermentasi (\%) } & \multirow[t]{2}{*}{ Rerata } \\
\hline & & 0 & 20 & 40 & \\
\hline \multirow[t]{4}{*}{ ADF } & 2 & $0,06^{\dagger} \pm 0,02$ & $0,09 e_{ \pm} \pm 0,02$ & $0,08^{e f} \pm 0,01$ & $0,07^{c} \pm 0,02$ \\
\hline & 3 & $0,15^{\mathrm{b}} \pm 0,01$ & $0,21^{a} \pm 0,01$ & $0,11^{\mathrm{cd}} \pm 0,03$ & $0,16^{a} \pm 0,02$ \\
\hline & 4 & $0,14^{\mathrm{b}} \pm 0,02$ & $0,13^{b c}{ }_{ \pm}, 01$ & $0,10^{\mathrm{de}_{ \pm}} \pm 0,01$ & $0,12^{\mathrm{b}} \pm 0,02$ \\
\hline & Rerata & $0,12^{\mathrm{b}} \pm 0,02$ & $0,14^{\mathrm{a}} \pm 0,01$ & $0,09^{c} \pm 0,02$ & \\
\hline \multirow[t]{4}{*}{ NDF } & 2 & $2,00^{a} \pm 1,16$ & $0,35^{\mathrm{b}} \pm 0,13$ & $0,60^{\mathrm{b}} \pm 0,33$ & $0,98^{a} \pm 1,62$ \\
\hline & 3 & $0,84^{\mathrm{b}} \pm 0,40$ & $0,78^{\mathrm{b}} \pm 0,18$ & $0,55^{\mathrm{b}} \pm 0,11$ & $0,72^{\mathrm{a}} \pm 0,69$ \\
\hline & 4 & $0,54^{\mathrm{b}} \pm 0,28$ & $0,79 \mathrm{~b} \pm 0,04$ & $0,77^{\mathrm{b}} \pm 0,10$ & $0,70^{a} \pm 0,14$ \\
\hline & Rerata & $1,13^{a} \pm 0,61$ & $0,64^{\mathrm{b}} \pm 0,12$ & $0,64^{\mathrm{b}} \pm 0,54$ & \\
\hline \multirow[t]{4}{*}{ Selulosa } & 2 & $0,03 \pm 0,01$ & $0,04 \pm 0,01$ & $0,01 \pm 0,01$ & $0,03 \pm 0,01$ \\
\hline & 3 & $0,04 \pm 0,02$ & $0,02 \pm 0,01$ & $0,02 \pm 0,01$ & $0,03 \pm 0,01$ \\
\hline & 4 & $0,02 \pm 0,01$ & $0,01 \pm 0,01$ & $0,07 \pm 0,01$ & $0,03 \pm 0,01$ \\
\hline & Rerata & $0,03 \pm 0,01$ & $0,02 \pm 0,01$ & $0,03 \pm 0,01$ & \\
\hline \multirow[t]{4}{*}{ Hemiselulosa } & 2 & $1,94^{a} \pm 1,16$ & $0,26^{b} \pm 0,15$ & $0,52^{b} \pm 0,32$ & $0,91^{a} \pm 0,54$ \\
\hline & 3 & $0,69^{b} \pm 0,40$ & $0,57^{b} \pm 0,19$ & $0,44^{b} \pm 0,10$ & $0,57^{a} \pm 0,23$ \\
\hline & 4 & $0,40^{\mathrm{b}} \pm 0,28$ & $0,66^{\mathrm{b}} \pm 0,04$ & $0,67^{b} \pm 0,10$ & $0,57^{a} \pm 0,14$ \\
\hline & Rerata & $1,01^{a} \pm 0,61$ & $0,50^{\mathrm{b}} \pm 0,13$ & $0,54^{b} \pm 0,17$ & \\
\hline \multirow[t]{4}{*}{ Lignin } & 2 & $0,03^{e} \pm 0,01$ & $0,05^{\mathrm{de}} \pm 0,01$ & $0,06^{d} \pm 0,01$ & $0,05^{c} \pm 0,01$ \\
\hline & 3 & $0,11^{b c} \pm 0,02$ & $0,20^{a} \pm 0,01$ & $0,09^{c} \pm 0,02$ & $0,13^{a} \pm 0,02$ \\
\hline & 4 & $0,12^{\mathrm{b}} \pm 0,01$ & $0,12^{\mathrm{b}} \pm 0,01$ & $0,03^{e} \pm 0,01$ & $0,09^{b} \pm 0,01$ \\
\hline & Rerata & $0,09^{b} \pm 0,01$ & $0,12^{a} \pm 0,01$ & $0,06^{c} \pm 0,01$ & \\
\hline
\end{tabular}

Keterangan: a,b,c,d Superskrip berbeda pada baris dan kolom yang sama menunjukan perbedaan nyata $(\mathrm{P}<0,05)$.

Perlakuan pengolahan sinbiotik kultur campuran yang berasal dari kombinasi bekatul gandum sebagai prebiotik dan jus kubis terfermentasi sebagai probiotik melalui proses fermentasi tidak memberikan pengaruh pada parameter selulosa. Kadar selulosa pada faktor lama peram tidak mengalami perubahan. Hal ini dikarenakan selulosa merupakan hasil dari pengurangan ADF dikurangi lignin. Selulosa merupakan bagian dari ADF di mana selulosa adalah bagian yang larut dalam $\mathrm{H}_{2} \mathrm{SO}_{4} 72 \%$ (Preston and Leng, 1987; Van Soest et al., 1991). Rerata faktor penambahan jus kubis terfermentasi pada parameter selulosa menunjukkan tidak ada perbedaan nyata. Hal ini disebabkan oleh kadar serat kasar yang relatif kecil sehingga mikroba asal jus kubis terfermentasi cenderung merombak hemiselulosa. Hal ini tercermin dari penurunan kadar hemiselulosa pada faktor penambahan jus kubis terfermentasi. Penurunan dari 1,01 $\pm 0,61 \%$ (penambahan jus kubis terfermentasi $0 \%$ ) menurun menjadi $0,50 \pm 0,13 \%$ (penambahan jus kubis terfermentasi $20 \%$ ). Interaksi antara faktor lama peram dan penambahan jus kubis terfermentasi tidak memberikan perubahan pada parameter kadar selulosa. Presentase kadar serat kasar yang relatif kecil menunjukkan efektivitas kerja mikroba asal jus kubis terfermentasi cenderung merombak hemiselulosa. Hal ini terlihat dari menurunnya kadar hemiselulosa (Tabel 2), meningkatnya kadar arabinosa dan manosa (Tabel 3). Crampton and Haris (1969) menyatakan bahwa selulosa merupakan bagian dari ADF yang terlarut.

Perlakuan pengolahan sinbiotik kultur campuran yang berasal dari kombinasi bekatul gandum sebagai prebiotik dan jus kubis terfermentasi sebagai probiotik melalui proses fermentasi memberikan pengaruh nyata 
pada penurunan kadar hemiselulosa $(p<0,05)$. Kadar hemiselulosa tertinggi sebesar $1,94 \pm 1,16 \%$ sedangkan terendah $0,40 \pm 0,28 \%$ (Tabel 2). Rerata kandungan hemiselulosa pada faktor lama peram tidak memperlihatkan perubahan pada parameter hemiselulosa. Hal ini disebabkan oleh efisiensi kerja mikroorganisme yang terkandung dalam jus kubis terfermentasi mampu bekerja optimal dalam kurun waktu 48 jam. Kisaran waktu 2, 3, 4 hari tidak memberikan pengaruh pada perubahan kadar hemiselulosa. Carr et al. (2002) menyatakan kinerja optimum bakteri asam laktat adalah 48 jam. Rerata faktor penambahan jus kubis fermentasi menurunkan kadar hemiselulosa. Penurunan kadar hemiselulosa diakibatkan oleh proses pemanasan dengan autoclave pada suhu $121^{\circ} \mathrm{C}$ dan dilanjutkan oleh proses fermentasi yang melibatkan kinerja mikroorganisme pencerna serat yaitu Lactobacillus plantarum, Lactobacillus brevis dan Rhizopus oryzae. Penurunan kadar hemiselulosa diikuti penurunan nilai NDF. Kadar NDF perlakuan menurun dari 1,13 menjadi $0,64 \%$ pada faktor penambahan jus kubis terfermentasi sedangkan kadar NDF pada faktor lama peram menurun dari 0,98 menjadi 0,70\% dan juga diikuti oleh meningkatnya kadar arabinosa dan mannosa (Tabel 3). Crampton and Haris (1969) menyatakan bahwa penurunan kadar NDF diikuti dengan peningkatan kadar lignin dan penurunan kadar hemiselulosa. Kandungan hemiselulosa merupakan selisih kandungan NDF dan ADF (Preston and Leng, 1987; Van Soest et al., 1991). Interaksi antara faktor lama peram dan penambahan jus kubis terfermentasi memberikan perubahan pada parameter hemiselulosa. Kadar hemiselulosa mengalami penurunan pada lama peram 3 dan 4 hari dengan penambahan jus kubis terfermentasi 20 dan $40 \%$ namun pada lama peram 3 dan 4 hari tidak mengalami penurunan. Hal ini terjadi karena proses perombakan nutrien pada bekatul gandum yang dilakukan oleh mikroorganisme yang ada pada jus kubis fermentasi yang tercermin dalam Figur SEM pada Figur 1 sampai 3. Carr et al. (2002) menyatakan bahwa efektifitas kinerja bakteri asam laktat optimal pada 48 jam.

Tabel 3. Kandungan gross energi, glukosa, sukrosa, arabinosa dan mannosa sinbiotik kultur campuran yang berasal dari kombinasi bekatul gandum sebagai prebiotik dan jus kubis terfermentasi sebagai probiotik melalui proses fermentasi

\begin{tabular}{|c|c|c|c|c|c|}
\hline \multirow[t]{2}{*}{ Parameter } & \multirow{2}{*}{$\begin{array}{c}\text { Lama Peram } \\
\text { (Hari) }\end{array}$} & \multicolumn{3}{|c|}{ Penambahan Jus Kubis Terfermentasi (\%) } & \multirow[t]{2}{*}{ Rerata } \\
\hline & & 0 & 20 & 40 & \\
\hline Gross & 2 & $4269,33^{a} \pm 14,99$ & $4202,75^{\mathrm{bc}} \pm 6,94$ & $4176,20^{\mathrm{cd}} \pm 8,33$ & $4216,09^{b} \pm 10,09$ \\
\hline energi & 3 & $4271,04^{a} \pm 8,60$ & $4223,75^{\mathrm{b}} \pm 1,44$ & $4185,05^{\mathrm{bcd}} \pm 19,82$ & $4226,61^{a b} \pm 9,95$ \\
\hline \multirow[t]{2}{*}{$(\mathrm{kcal} / \mathrm{kg})$} & 4 & $4303,50^{\mathrm{a}} \pm 16,37$ & $4284,17^{\mathrm{a}} \pm 64,72$ & $4146,12^{\mathrm{d}} \pm 2,39$ & $4244,59^{a} \pm 27,83$ \\
\hline & Rerata & $4281,29 \mathrm{a} \pm 13,41$ & $4236,89^{b} \pm 24,37$ & $4169,12^{\mathrm{c}} \pm 10,18$ & \\
\hline \multirow{4}{*}{$\begin{array}{l}\text { Glukosa } \\
(\% \text { BK) }\end{array}$} & 2 & $0,45 \pm 0,01$ & $0,55 \pm 0,03$ & $0,25 \pm 0,03$ & $0,41^{a} \pm 0,03$ \\
\hline & 3 & $0,54 \pm 0,07$ & $0,36 \pm 0,03$ & $0,25 \pm 0,02$ & $0,38^{a} \pm 0,04$ \\
\hline & 4 & $0,66 \pm 0,04$ & $0,42 \pm 0,01$ & $0,29 \pm 0,01$ & $0,39 a \pm 0,02$ \\
\hline & Rerata & $0,48^{a} \pm 0,04$ & $0,45^{a} \pm 0,02$ & $0,26^{\mathrm{b}} \pm 0,02$ & \\
\hline \multirow{4}{*}{$\begin{array}{l}\text { Sukrosa } \\
(\% \text { BK) }\end{array}$} & 2 & $4,044^{a} \pm 0,06$ & $3,52^{b} \pm 0,03$ & $1,55^{f} \pm 0,05$ & $3,04{ }^{a} \pm 0,05$ \\
\hline & 3 & $2,46^{\mathrm{cd}} \pm 0,04$ & $2,56^{c} \pm 0,06$ & $2,44^{d} \pm 0,08$ & $2,49^{b} \pm 0,06$ \\
\hline & 4 & $1,69 e_{ \pm} \pm 0,05$ & $0,9^{h} \pm 0,05$ & $1,249 \pm 0,11$ & $1,288_{ \pm} \pm 0,07$ \\
\hline & Rerata & $2,73^{a} \pm 0,05$ & $2,33^{b} \pm 0,05$ & $1,74^{\mathrm{c}} \pm 0,08$ & \\
\hline \multirow{4}{*}{$\begin{array}{l}\text { Arabinosa } \\
(\% \mathrm{BK})\end{array}$} & 2 & $0,22^{\mathrm{cd}_{ \pm}} \pm 0,01$ & $0,30^{a} \pm 0,03$ & $0,20^{\mathrm{de}_{ \pm}} \pm, 01$ & $0,24^{a} \pm 0,01$ \\
\hline & 3 & $0,21^{\mathrm{de}} \pm 0,01$ & $0,25^{b c} \pm 0,02$ & $0,28^{a b} \pm 0,02$ & $0,25^{a} \pm 0,01$ \\
\hline & 4 & $0,18^{e} \pm 0,02$ & $0,20^{\mathrm{de}_{ \pm}} \pm 0,01$ & $0,26^{b} \pm 0,02$ & $0,21^{b} \pm 0,01$ \\
\hline & Rerata & $0,20^{\mathrm{b}} \pm 0,01$ & $0,25 a \pm 0,02$ & $0,25^{a} \pm 0,01$ & \\
\hline \multirow{4}{*}{$\begin{array}{l}\text { Mannosa } \\
(\% \text { BK) }\end{array}$} & 2 & $0,13^{c} \pm 0,01$ & $0,266^{a} \pm 0,03$ & $0,22^{\mathrm{b}} \pm 0,02$ & $0,20^{a b} \pm 0,02$ \\
\hline & 3 & $0,16^{c} \pm 0,03$ & $0,24^{a b} \pm 0,01$ & $0,25^{a b} \pm 0,02$ & $0,22^{a} \pm 0,02$ \\
\hline & 4 & $0,21^{b} \pm 0,02$ & $0,21^{b} \pm 0,02$ & $0,15^{c} \pm 0,03$ & $0,19^{b} \pm 0,02$ \\
\hline & Rerata & $0,17^{c} \pm 0,02$ & $0,24 a \pm 0,02$ & $0,21^{b} \pm 0,02$ & \\
\hline
\end{tabular}

Keterangan: a,b,c,d Superskrip berbeda pada baris dan kolom yang sama menunjukan perbedaan nyata $(\mathrm{P}<0,05)$.

Perlakuan pengolahan sinbiotik kultur campuran yang berasal dari kombinasi bekatul gandum sebagai prebiotik dan jus kubis terfermentasi sebagai probiotik melalui proses fermentasi memberikan pengaruh nyata pada peningkatan kadar lignin $(p<0,05)$. Rerata kandungan lignin pada faktor lama peram mengalami kenaikan dari $0,05 \pm 0,01 \%$ menjadi $0,09 \pm 0,01 \%$. Meningkatnya kadar lignin juga diikuti meningkatnya kadar ADF. Lignin merupakan bagian dari ADF dimana lignin merupakan bagian yang tidak larut dalam $\mathrm{H}_{2} \mathrm{SO}_{4}$ 72\% (Preston and Leng, 1987; Van Soest et al., 1991). Rerata faktor penambahan jus kubis terfermentasi mengalami peningkatan dari $0,05 \pm 0,01$ menjadi $0,13 \pm 0,02 \%$. Peningkatan kadar lignin disebabkan oleh adanya penurunan nilai NDF. Crampton and Haris (1969) menyatakan bahwa penurunan kadar NDF diikuti 
dengan peningkatan kadar lignin dan penurunan kadar hemiselulosa. Interaksi antara faktor lama peram dan penambahan jus kubis terfermentasi memberikan pengaruh pada parameter lignin. Kadar lignin mengalami peningkatan seiring dengan lama peram dan penambahan jus kubis terfermentasi. Kadar lignin perlakuan cenderung sama pada perlakuan lama peram 2 hari, namun pada lama peram 3 dan 4 hari mengalami peningkatan. Hal ini dimungkinkan oleh adanya miselium yang terbentuk dari proses fermentasi yang diakibatkan oleh kinerja kapang Rhizopus oryze sehingga kadar ligninnya mengalami peningkatan. Lignin merupakan bagian dari ADF di mana lignin merupakan bagian yang tidak larut dalam $\mathrm{H}_{2} \mathrm{SO}_{4} 72 \%$ (Preston and Leng, 1987; Van Soest et al., 1991).

Gross energi, glukosa, sukrosa, arabinosa, manosa dan rafinosa

Perlakuan pengolahan sinbiotik kultur campuran yang berasal dari kombinasi bekatul gandum sebagai prebiotik dan jus kubis terfermentasi sebagai probiotik melalui proses fermentasi memberikan pengaruh pada perubahan kadar gross energi $(p<0,05)$. Kadar gross energi tertinggi sebesar 4303,50 $\pm 16,37 \mathrm{kcal} / \mathrm{kg}$ sedangkan terendah 4146,12 $\pm 2,39 \mathrm{kcal} / \mathrm{kg}$ (Tabel 3). Rerata penambahan jus kubis terfermentasi menurunkan kadar gross energi dari 4281,29 $\pm 13,41$ $\mathrm{kcal} / \mathrm{kg}$ menjadi $4169,12 \pm 10,18 \mathrm{kcal} / \mathrm{kg}$. Kandungan gross energi pada penambahan jus kubis terfermentasi 0, 20 dan $40 \%$ mengalami penurunan. Penurunan ini terjadi disebabkan oleh proses fermentasi. Kandungan jus kubis terfermentasi terdiri dari Lactobacillus plantarum, Lactobacillus brevis, Rhizopus oryzae dan Saccharomyces cerevise yang menggunakan sumber karbohidrat sebagai nutrien bagi perkembangan tubuh mikroorganisme (Utama et al., 2018b). Rerata faktor lama peram 4 hari lebih tinggi dibanding dengan lama peram 2 hari. Perbedaan tersebut disebabkan oleh peningkatan kadar serat kasar dan ADF serta menurunnya kadar glukosa, sukrosa, arabinosa dan mannosa (Tabel 1, 2 dan 3). Serat kasar merupakan fraksi karbohidrat yang telah dipisahkan dengan BETN yang tidak larut dalam basa dan asam encer setelah pendidihan selama 30 menit. Serat kasar terdiri atas selulosa, hemiselulosa dan lignin yang sulit dicerna. Kadar serat kasar yang berbeda pada bahan penyusun pakan dapat mempengaruhi nilai energi yang tersedia dalam pakan (Wahyu, 1994). Kandungan ADF dapat digunakan untuk menduga besaran energi pada bahan pakan berserat (Jung, 1997). Hasil perombakan sumber karbohidrat akan digunakan sebagai sumber energi. Miller and Wollin, (1996) menyatakan bahwa bakteri asam laktat memanfaatkan sumber karbohidrat yang dihidrolisis menjadi asam laktat, asam lemak rantai pendek dan energi. Interaksi antara faktor lama peram dan penambahan jus kubis terfermentasi terjadi penurunan pada parameter gross energi. Interaksi ini menandakan bahwa kinerja bakteri asal jus kubis terfermentasi sangat optimal dan mampu berperan sebagai sinbiotik. Hal ini terlihat dari penurunan kadar glukosa, sukrosa, rafinosa dan pati resisten yang merupakan indikator dari kinerja mikroorganisme asal jus kubis terfermentasi (Tabel 3 dan 4). Penurunan tersebut diduga disebabkan oleh kinerja enzim yang dihasilkan oleh Lactobacillus plantarum yang mampu memecah senyawa kompleks menjadi senyawa yang lebih sederhana sehingga dapat dimanfaatkan untuk metabolisme sel (Giraud and Williams, 2000).

Perlakuan pengolahan sinbiotik kultur campuran yang berasal dari kombinasi bekatul gandum sebagai prebiotik dan jus kubis terfermentasi sebagai probiotik melalui proses fermentasi memberikan pengaruh pada penurunan kadar glukosa $(\mathrm{p}<0,05)$. Rerata penambahan jus kubis terfermentasi menurunkan kadar glukosa dari $0,48 \pm 0,04$ menjadi $0,26 \pm 0,02 \%$. Penurunan kadar glukosa disebabkan oleh proses fermentasi yang dilakukan oleh mikroorganisme yang berada pada jus kubis terfermentasi. Kandungan jus kubis terfermentasi terdiri dari Lactobacillus plantarum, Lactobacillus brevis, Rhizopus oryzae dan Saccharomyces cerevise yang menggunakan sumber karbohidrat sebagai nutrien bagi perkembangan tubuh mikroorganisme. Selama proses fermentasi, bakteri asam laktat mengubah glukosa menjadi asam laktat melalui Embden Meyerhoff Pathway (EMP). Media dengan sumber utama glukosa menghasilkan asam laktat sekitar 90\% (Salminen and Wright, 1993). Kadar glukosa merupakan cerminan energi yang terkandung didalam bahan pakan. Penurunan kadar glukosa seiring dengan peningkatan kandungan gross energi (Tabel 3). Glukosa dalam proses metabolisme merupakan bentuk karbohidrat yang beredar di dalam tubuh dan di dalam sel yang merupakan sumber energi (Hodge and Osman, 1976; Cristofaro, et al., 1994). Rerata faktor lama peram tidak memperlihatkan perbedaan nyata antar perlakuan. Hal ini disebabkan oleh efisiensi kinerja mikroorganisme yang terkandung dalam jus kubis terfermentasi mampu bekerja optimal dalam kurun waktu 48 jam. Kisaran waktu 2, 3, 4 hari tidak memberikan pengaruh yang berarti pada perubahan kadar glukosa. Carr et al. (2002) menyatakan kinerja optimum bakteri asam laktat adalah 48 jam. Hasil perombakan sumber karbohidrat dapat digunakan sebagai sumber energi. Miller and Wollin (1996) menyatakan bahwa bakteri asam laktat memanfaatkan sumber karbohidrat yang dihidrolisis menjadi asam laktat, asam lemak rantai pendek dan energi. Interaksi antara faktor lama peram dan penambahan jus kubis terfermentasi tidak memperlihatkan perubahan pada parameter kadar glukosa. Tabel 3 memperlihatkan tren penurunan pada faktor lama pemeraman dan penambahan jus kubis terfermentasi untuk parameter glukosa. Penurunan tersebut diduga disebabkan oleh kinerja enzim yang dihasilkan oleh Lactobacillus plantarum yang mampu memecah senyawa kompleks menjadi senyawa yang 
lebih sederhana sehingga dapat dimanfaatkan untuk metabolisme sel (Giraud and Williams, 2000).

Perlakuan pengolahan sinbiotik kultur campuran yang berasal dari kombinasi bekatul gandum sebagai prebiotik dan jus kubis terfermentasi sebagai probiotik melalui proses fermentasi memberikan pengaruh pada penurunan kadar sukrosa $(p<0,05)$. Rerata penambahan jus kubis terfermentasi dan lama peram menurunkan kadar sukrosa masing-masing dari 2,73 $\pm 0,05$ menjadi $1,74 \pm 0,08 \%$ dan $3,04 \pm 0,05$ menjadi $1,28 \pm 0,07 \%$. Penurunan kadar sukrosa disebabkan oleh proses fermentasi yang dilakukan oleh mikroorganisme yang berada pada jus kubis terfermentasi yang menggunakan sumber karbohidrat sebagai nutrien bagi perkembangan tubuh mikroorganisme. Penurunan kadar sukrosa diduga terjadi karena pemanfaatan gula dan polisakarida yang terkandung dalam bekatul gandum sebagai sumber karbon dan energi untuk pertumbuhan Lactobacillus plantarum, Lactobacillus brevis, Rhizopus oryzae dan Saccharomyces cerevise. Charalampopoulus et al. (2002) menyatakan bahwa Lactobacillus plantarum mampu memanfaatkan gula sederhana sebagai nutrisi sebesar (43\%) pada fase eksponensial. Rerata faktor lama peram memperlihatkan penurunan kadar sukrosa. Semakin lama pemeraman kadar sukrosa semakin menurun. Penurunan sukrosa disebabkan oleh perombakan karbohidrat sederhana yang dimanfaatkan mikroorganisme sebagai sumber energi. Miller and Wollin, (1996) menyatakan bahwa bakteri asam laktat memanfaatkan sumber karbohidrat yang dihidrolisis menjadi asam laktat, asam lemak rantai pendek dan energi. Interaksi antara faktor lama peram dan penambahan jus kubis terfermentasi memperlihatkan penurunan pada parameter kadar sukrosa. Semakin lama pemeraman dan semakin banyak jumlah jus kubis terfermentasi yang ditambahkan, kadar sukrosa semakin menurun. Penurunan tersebut diduga disebabkan oleh kinerja enzim yang dihasilkan oleh bakteri asam laktat yang mampu memecah senyawa kompleks menjadi senyawa sederhana sehingga dapat dimanfaatkan untuk metabolisme sel (Giraud and Williams, 2000). Yoon et al., (2004) menyatakan bahwa kultur bakteri asam laktat menyebabkan penurunan level gula pada jus tomat terfermentasi dimana Lactobacillus plantarum mengkonsumsi gula lebih cepat dibanding Lactobacillus casei. Menurut Oberman (1985), peningkatan jumlah bakteri menyebabkan peningkatan kebutuhan senyawa yang dirombak menjadi asam laktat dan energi.

Perlakuan pengolahan sinbiotik kultur campuran yang berasal dari kombinasi bekatul gandum sebagai prebiotik dan jus kubis terfermentasi sebagai probiotik melalui proses fermentasi memberikan pengaruh pada perubahan kadar arabinosa $(\mathrm{P}<0,05)$. Kadar arabinosa tertinggi sebesar $0,30 \pm 0,03 \%$ sedangkan terendah pada $0,18 \pm 0,02 \%$ (Tabel 3 ). Rerata penambahan jus kubis terfermentasi meningkatkan kadar arabinosa dari $0,20 \pm 0,01 \%$ menjadi $0,25 \pm 0,01 \%$. Peningkatan kadar arabinosa diakibatkan oleh penambahan jus kubis fermentasi dan menurunnya kadar hemiselulosa (Tabel 2). Rerata lama peram menurunkan kadar arabinosa dari $0,24 \pm 0,01 \%$ menjadi $0,21 \pm 0,01 \%$. Penurunan kadar arabinosa disebabkan oleh kinerja mikroorganisme didalam jus kubis fermentasi. Kandungan jus kubis terfermentasi terdiri dari Lactobacillus plantarum, Lactobacillus brevis, Rhizopus oryzae dan Saccharomyces cerevise yang menggunakan sumber karbohidrat sebagai nutrien bagi perkembangan tubuh mikroorganisme. Lactobacillus brevis dan Lactobacillus plantarum memiliki aktivitas enzim selulase yang dapat menghidrolisis selulosa menjadi glukosa (Narasimha et al., 2006). Krabi et al. (2015) menyatakan bahwa Lactobacillus sp. mampu memproduksi enzim ekstra seluler yaitu $2,67 \%$ enzim pektinase, $8 \%$ enzim $\beta$ glukosidase dan 5,33\% enzim selulase. Enzim selulase yang dihasilkan oleh Lactobacillus sp. dapat dimanfaatkan untuk meningkatkan kecernaan dan mendegradasi pakan berserat. Interaksi antara faktor lama peram dan penambahan jus kubis terfermentasi memperlihatkan peningkatan kadar arabinosa. Semakin lama pemeraman dan semakin banyak jumlah jus kubis terfermentasi yang ditambahkan, kadar arabinosa semakin meningkat. Peningkatan ini disebabkan oleh perombahan komponen serat pada bekatul gandum sehingga mempengaruhi kadar arabinosa. Arabinosa merupakan bagian rantai hemiselulosa yang terlepas pada saat terdegradasi oleh mikrobia yang berasal dari jus kubis terfermentasi. Walter and Kohler (1981) menyatakan bahwa Lactobacillus sp. mampu menghasilkan selulase yang memecah serat dalam saluran pencernaan. Aktivitas enzim selulase dicapai dalam waktu inkubasi 24-48 jam. Lactobacillus plantarum mampu menurunkan serat pada bekatul padi sebesar 0,3\% setelah 12 jam inkubasi (Zubaidah et al.,2012).

Perlakuan pengolahan sinbiotik kultur campuran yang berasal dari kombinasi bekatul gandum sebagai prebiotik dan jus kubis terfermentasi sebagai probiotik melalui proses fermentasi memberikan pengaruh pada peningkatan kadar mannosa $(p<0,05)$. Kadar mannosa tertinggi sebesar $0,26 \pm 0,03 \%$ sedangkan terendah $0,13 \pm 0,01 \%$ (Tabel 3). Rerata penambahan jus kubis fermentasi meningkatkan kadar mannosa dari $0,17 \pm 0,02 \%$ menjadi $0,24 \pm 0,02 \%$. Hal ini disebabkan oleh penambahan jus kubis terfermentasi yang mengandung molases sebagai sumber mannosa. Mannosa merupakan monomer dari glukosa (Hartadi et al., 1997). Rerata lama peram menurunkan kadar mannosa dari $0,20 \pm 0,02$ menjadi $0,19 \pm 0,02 \%$. Penurunan kadar mannosa disebabkan oleh proses fermentasi yang terjadi. Penurunan ini disebabkan kinerja mikroorganisme didalam jus kubis fermentasi. Jus kubis fermentasi mengandung jenis Lactobacillus plantarum, Lactobacillus brevis, Rhizopus oryzae dan Saccaromyces cerevise. Mikroorganisme ini merupakan pencerna karbohidrat dan mempunyai sifat hetero 
fermentatif yaitu menghasilkan alkohol dan asam laktat (Miller and Wollin, 1996). Interaksi antara faktor lama peram dan penambahan jus kubis terfermentasi memperlihatkan peningkatan kadar mannosa. Semakin lama pemeraman dan semakin banyak jumlah jus kubis afkir terfermentasi yang ditambahkan, kadar mannosa semakin meningkat. Peningkatan ini disebabkan oleh perombahan komponen glukosa dan karbohidrat sederhana pada bekatul gandum sehingga mempengaruhi kadar mannosa. Peningkatan kadar mannosa seiring dengan penurunan kadar glukosa, sukrosa (Tabel 3) dan BETN (Tabel 1). Bakteri asam laktat dalam medium dapat memfermentasi atau menghidrolisis gula menjadi komponen-komponen yang lebih sederhana menjadi asam laktat, asam organik, $\mathrm{CO}_{2}, \mathrm{H}_{2} \mathrm{O}$ dan energi (Lewthwaite et al., 1997).

Tabel 4. Kandungan rafinosa, amilum, amilosa, amilopektin dan pati resisten sinbiotik kultur campuran yang berasal dari kombinasi bekatul gandum sebagai prebiotik dan jus kubis terfermentasi sebagai probiotik melalui proses fermentasi

\begin{tabular}{|c|c|c|c|c|c|}
\hline \multirow{2}{*}{$\begin{array}{l}\text { Parameter (\% } \\
\text { BK) }\end{array}$} & \multirow[t]{2}{*}{ Lama Peram (Hari) } & \multicolumn{3}{|c|}{ Penambahan Jus Kubis Terfermentasi (\%) } & \multirow{2}{*}{ Rerata } \\
\hline & & 0 & 20 & 40 & \\
\hline \multirow{4}{*}{ Rafinosa } & 2 & $1,24{ }^{c} \pm 0,04$ & $0,85^{\ddagger} \pm 0,05$ & $1,95^{\mathrm{a}} \pm 0,01$ & $1,37 a \pm 0,03$ \\
\hline & 3 & $1,17^{d} \pm 0,04$ & $0,78^{9} \pm 0,05$ & $1,65^{b} \pm 0,03$ & $1,20^{b} \pm 0,03$ \\
\hline & 4 & $0,89 e^{e} \pm 0,05$ & $0,11^{\mathrm{i}} \pm 0,05$ & $0,35^{h} \pm 0,05$ & $0,42^{c} \pm 0,04$ \\
\hline & Rerata & $1,10^{\mathrm{b}} \pm 0,04$ & $0,58^{c} \pm 0,05$ & $1,32^{\mathrm{a}} \pm 0,01$ & \\
\hline \multirow[t]{4}{*}{ Amilosa } & 2 & $3,68^{c} \pm 0,15$ & $2,94 \mathrm{e}_{ \pm} \pm 0,15$ & $3,81^{b c} \pm 0,15$ & $3,48^{b} \pm 0,15$ \\
\hline & 3 & $2,97^{e} \pm 0,07$ & $3,83^{b c} \pm 0,22$ & $3,28^{d} \pm 0,11$ & $3,36^{b} \pm 0,13$ \\
\hline & 4 & $3,98^{b} \pm 0,15$ & $4,29 \mathrm{a} \pm 0,16$ & $3,73^{b c} \pm 0,07$ & $4,00^{a} \pm 0,13$ \\
\hline & Rerata & $3,54^{a} \pm 0,12$ & $3,69^{a} \pm 0,18$ & $3,61^{a} \pm 0,11$ & \\
\hline \multirow[t]{4}{*}{ Amilum } & 2 & $43,69^{f} \pm 0,30$ & $46,56^{\mathrm{e}} \pm 0,10$ & $49,40^{c} \pm 0,19$ & $46,55^{\mathrm{b}} \pm 0,20$ \\
\hline & 3 & $48,67^{d} \pm 0,56$ & $41,72^{g} \pm 0,31$ & $46,65^{e} \pm 0,24$ & $45,68^{c} \pm 0,37$ \\
\hline & 4 & $41,619 \pm 0,25$ & $51,40^{\mathrm{b}} \pm 0,14$ & $53,62^{a} \pm 0,36$ & $48,88^{a} \pm 0,25$ \\
\hline & Rerata & $44,66^{c} \pm 0,37$ & $46,56^{b} \pm 0,18$ & $49,89^{a} \pm 0,26$ & \\
\hline \multirow[t]{4}{*}{ Amilopektin } & 2 & $40,01^{\mathrm{e}} \pm 0,15$ & $43,62^{\mathrm{d}} \pm 0,15$ & $45,59^{c} \pm 0,04$ & $43,07^{b} \pm 0,11$ \\
\hline & 3 & $45,70^{c} \pm 0,49$ & $37,89^{f} \pm 0,09$ & $43,37^{d} \pm 0,13$ & $42,32^{c} \pm 0,24$ \\
\hline & 4 & $37,63^{f} \pm 0,10$ & $47,11^{\mathrm{b}} \pm 0,30$ & $49,89^{a} \pm 0,29$ & $44,88^{a} \pm 0,23$ \\
\hline & Rerata & $41,11^{c} \pm 0,25$ & $42,87^{b} \pm 0,18$ & $46,28^{a} \pm 0,15$ & \\
\hline \multirow[t]{4}{*}{ Pati resisten } & 2 & $7,96^{a} \pm 0,02$ & $6,71^{c} \pm 0,03$ & $4,199 \pm 0,02$ & $6,28^{a} \pm 0,03$ \\
\hline & 3 & $6,08^{d} \pm 0,03$ & $7,76^{a} \pm 0,08$ & $4,67^{\mathfrak{1} \pm 0,43}$ & $6,17^{a} \pm 0,18$ \\
\hline & 4 & $7,37^{b} \pm 0,02$ & $5,03^{e} \pm 0,02$ & $3,60^{h} \pm 0,02$ & $5,33^{b} \pm 0,02$ \\
\hline & Rerata & $7,14^{a} \pm 0,02$ & $6,50^{b} \pm 0,04$ & $4,15^{c} \pm 0,16$ & \\
\hline
\end{tabular}

Keterangan: a,b,c,d Superskrip berbeda pada baris dan kolom yang sama menunjukan perbedaan nyata $(\mathrm{P}<0,05)$.

Kandungan rafinosa, amilum, amilosa, amilopektin dan resistant starch

Perlakuan pengolahan sinbiotik kultur campuran yang berasal dari kombinasi bekatul gandum sebagai prebiotik dan jus kubis terfermentasi sebagai probiotik melalui proses fermentasi memberikan pengaruh pada penurunan kadar rafinosa $(p<0,05)$. Kadar rafinosa tertinggi sebesar $1,95 \pm 0,01 \%$ sedangkan terendah sebesar $0,11 \pm 0,05 \%$ (Tabel 4). Rerata penambahan jus kubis terfermentasi meningkatkan kadar rafinosa dari $1,10 \pm 0,04$ menjadi $1,32 \pm 0,01 \%$. Hal ini disebabkan oleh penambahan jus kubis afkir terfermentasi. Semakin banyak jus kubis afkir terfermentasi yang ditambahkan semakin tinggi kadar rafinosanya. Hal ini disebabkan oleh penambahan jus kubis afkir terfermentasi yang mengandung molases sebagai sumber rafinosa (Hartadi et al., 1997). Rerata lama peram menurunkan kadar rafinosa dari $1,37 \pm 0,03$ menjadi $0,42 \pm 0,04 \%$. Penurunan kadar rafinosa disebabkan oleh proses fermentasi yang terjadi. Hal ini disebabkan oleh aktivitas mikrobia yang berada pada jus kubis afkir terfermentasi yang mampu memanfaatkan rafinosa sebagai sumber energi bagi pertumbuhan mikrobia. Kearsley (1988) menyatakan bahwa rafinosa dapat terhidrolisis menjadi melibiosa dan fruktosa dengan bantuan enzim invertase yang terdapat pada khamir Saccharomyces cerevise. Interaksi antara faktor lama peram dan penambahan jus kubis terfermentasi terjadi penurunan kadar rafinosa. Interaksi ini menandakan bahwa kinerja bakteri asal jus kubis terfermentasi sangat optimal dan mampu berperan sebagai sinbiotik. Hal ini terlihat dari penurunan kadar rafinosa dan pati resisten yang merupakan indikator dari kinerja mikroorganisme asal jus kubis terfermentasi. Jus kubis terfermentasi mengandung khamir Saccharomyces cerevise sehingga mampu menurunkan kadar rafinosa. Komponen serat fraksi oligosakarida seperti rafinosa, verbakosa dan stakhiosa berpotensi sebagai prebiotik, yaitu subtrat yang dapat menstimulasi pertumbuhan bakteri probiotik. Prebiotik / serat pangan yang terdapat pada substrat dapat berfungsi sebagai prebiotik bagi bakteri probiotik melalui proses fermentasi, sehingga dihasilkan efek sinbiotik dan bersifat pangan fungsional (Irma et al., 2015).

Perlakuan pengolahan sinbiotik kultur campuran yang berasal dari kombinasi bekatul gandum sebagai prebiotik dan jus kubis terfermentasi sebagai probiotik 
melalui proses fermentasi memberikan pengaruh peningkatan kadar amilosa $(p<0,05)$. Kadar amilosa tertinggi sebesar $4,29 \pm 0,16 \%$ sedangkan terendah sebesar 2,94 $\pm 0,15 \%$ (Tabel 4). Rerata penambahan jus kubis terfermentasi tidak meningkatkan kadar amilosa. Hal ini terjadi karena lama peram 4 hari belum mampu merombak ikatan amilosa. Hustiany (2006) menyatakan bahwa rantai lurus amilosa yang membentuk sulur ganda kristal tersebut tahan terhadap amilase. Rerata lama peram memberikan peningkatan kadar amilosa

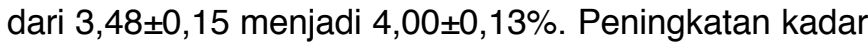
amilosa disebabkan oleh proses pengolahan pendahuluan yaitu pemanasan dengan autoclave pada suhu $121^{\circ} \mathrm{C}$, sehingga terjadi proses retrogradasi berulang. Penelitian Marsono (1998) pada gembili, suweg, uwi, entik, sukun, pisang, beras dan melinjo dengan proses pemanasan dapat mengakibatkan pembentukan pati resisten. Hal tersebut mengakibatkan mikoorganisme yang berada pada jus kubis terfermentasi belum mampu merombak amilosa menjadi senyawa sederhana dengan waktu fermentasi 4 hari. Menurut Taggart (2004), amilosa memiliki kemampuan membentuk kristal karena struktur rantai polimernya yang sederhana. Strukturnya yang sederhana ini dapat membentuk interaksi molekular yang kuat sehingga tahan terhadap enzim amilase. Peningkatan kadar amilosa juga dipengaruhi oleh penurunan kadar pati resisten. Huang and Rooney (2001) menyatakan bahwa peningkatan kadar pati resisten sangat dipengaruhi kadar amilosa bahan. Pati resisten paling besar terbentuk dari retrogradasi amilosa dan proses kristalisasi amilosa (Eerlingen et al., 1993). Interaksi antara faktor lama peram dan penambahan jus kubis terfermentasi terjadi peningkatan kadar amilosa. Interaksi ini menandakan bahwa kinerja bakteri asal jus kubis terfermentasi mampu berperan sebagai sinbiotik. Hal ini terlihat dari penurunan kadar pati resisten yang merupakan indikator dari kinerja mikroorganisme asal jus kubis terfermentasi (Tabel 4). Bengmark (2001) menyatakan bahwa sinbiotik merupakan produk fermentasi yang berasal dari peningkatan kemampuan bakteri probiotik yang disebabkan oleh tersedianya substrat spesifik (prebiotik) untuk melakukan fermentasi.

Perlakuan pengolahan sinbiotik kultur campuran yang berasal dari kombinasi bekatul gandum sebagai prebiotik dan jus kubis terfermentasi sebagai probiotik melalui proses fermentasi memberikan pengaruh pada peningkatan kadar amilum $(p<0,05)$. Kadar amilum tertinggi sebesar $53,62 \pm 0,36 \%$ sedangkan terendah $41,61 \pm 0,25 \%$. Rerata penambahan jus kubis afkir terfermentasi meningkatkan kadar amilum dari $44,66 \pm 0,37 \%$ menjadi 49,89 $\pm 0,26 \%$. Amilum (pati) terdiri dari amilosa dan amilopektin. Peningkatan kadar amilum disebabkan oleh proses pengolahan pendahuluan yaitu pemanasan dengan autoclave pada suhu $121^{\circ} \mathrm{C}$, sehingga terjadi proses gelatinisasi (Utama et al., 2019). Gelatinisasi terjadi apabila granula pati dipanaskan di dalam air, sehingga energi panas menyebabkan ikatan hidrogen terputus dan air masuk ke dalam granula pati. Gelatinisasi diawali dengan pembengkakan yang irreversible granula pati dalam air panas dan retrogradasi pati sebagai akibat proses pemanasan (Wurzburg, 1989; Sajilata et al., 2006). Marsono (1998) menyatakan bahwa retrogradasi dapat mengubah struktur pati yang mengarah ke pembentukan struktur kristalin baru sehingga pati tidak mudah terlarut. Hal ini mengakibatkan mikoorganisme yang berada pada jus kubis afkir terfermentasi belum mampu merombak amilum menjadi senyawa sederhana dengan waktu fermentasi 4 hari. Rerata faktor lama peram meningkatkan kadar amilum dari 46,55 $\pm 0,20 \%$ menjadi $48,88 \pm 0,25 \%$. Kenaikan amilum juga diikuti oleh kenaikan amilosa dan amilopektin namun terjadi penurunan pada pati resisten (Tabel 4). Amilum memiliki proporsi amilopektin yang jauh lebih besar jika dibandingkan dengan amilosa. Amilosa dan amilopektin di dalam granula pati dihubungkan dengan ikatan hidrogen (Wurzburg, 1989). Interaksi antara faktor lama peram dan penambahan jus kubis terfermentasi terjadi peningkatan yang signifikan terhadap parameter amilum. Peningkatan kadar amilum diikuti dengan penurunan kadar pati resisten dan rafinosa. Interaksi ini menandakan bahwa lama peram dan penambahan jus kubis terfermentasi pada bekatul gandum mampu bersinergi menghasilkan sinbiotik. Sinbiotik merupakan produk fermentasi yang berasal dari peningkatan kemampuan bakteri probiotik yang disebabkan oleh tersedianya substrat spesifik (prebiotik) untuk melakukan fermentasi. Prebiotik/serat pangan yang terdapat pada substrat dapat berfungsi sebagai prebiotik bagi bakteri probiotik melalui proses fermentasi, sehingga dihasilkan efek sinbiotik dan bersifat fungsional (Bengmark, 2001; Irma et al., 2015).

Perlakuan pengolahan sinbiotik kultur campuran yang berasal dari kombinasi bekatul gandum sebagai prebiotik dan jus kubis terfermentasi sebagai probiotik melalui proses fermentasi memberikan pengaruh pada peningkatan kadar amilopektin $(p<0,05)$. Kadar amilopektin mengalami peningkatan pada faktor lama peram maupun penambahan jus kubis terfermentasi (Tabel 4). Kadar amilopektin tertinggi sebesar $49,89 \pm 0,29 \%$ sedangkan terendah sebesar $37,63 \pm 0,10 \%$. Rerata penambahan jus kubis terfermentasi meningkatkan kadar amilopektin dari $41,11 \pm 0,25$ menjadi $46,28 \pm 0,15 \%$. Peningkatan kadar amilopektin linier dengan peningkatan amilosa dan amilum. Hustiany (2006) menyatakan bahwa struktur granula pati, amilosa dan amilopektin tersusun dalam suatu cincin-cincin, yang terdiri atas cincin lapisan amorf dan cincin lapisan semikristal. Rerata lama peram meningkatkan kadar amilopektin dari 43,07 $\pm 0,11$ menjadi 44,88 $\pm 0,23 \%$. Peningkatan kadar amilopektin disebabkan oleh peningkatan kadar amilosa dan amilum. Kadar amilopektin diperoleh dari pengurangan amilum dikurangi amilosa. Bahan sumber pati ketika dipanaskan, dapat membentuk lapisan yang transparan, yaitu larutan dengan viskositas tinggi dan berbentuk lapisan seperti untaian tali yang disebut amilopektin. Amilopektin cenderung tidak terjadi retrogradasi dan tidak membentuk gel, kecuali pada konsentrasi tinggi (Belitz and Grossch 1999). Interaksi antara faktor lama peram dan penambahan jus kubis terfermentasi terjadi 
peningkatan kadar amilopektin. Interaksi ini menandakan bahwa kinerja bakteri asal jus kubis terfermentasi sangat optimal dan mampu berperan sebagai sinbiotik. Hal ini terlihat dari penurunan kadar hemiselulosa, NDF (Tabel 2), arabinosa, mannosa (Tabel 3), rafinosa dan pati resisten (Tabel 4) yang merupakan indikator dari kinerja mikroorganisme asal jus kubis terfermentasi. Komponen polisakarida dan oligosakarida pada bekatul gandum mampu berperan sebagai prebiotik, yaitu subtrat yang dapat menstimulasi pertumbuhan bakteri probiotik (Utama et al., 2019). Irma et al. (2015) menyatakan bahwa prebiotik yang terdapat pada substrat dapat berfungsi sebagai prebiotik bagi bakteri probiotik melalui proses fermentasi, sehingga dihasilkan efek sinbiotik dan pakan fungsional.

Perlakuan pengolahan sinbiotik kultur campuran yang berasal dari kombinasi bekatul gandum sebagai prebiotik dan jus kubis terfermentasi sebagai probiotik melalui proses fermentasi memberikan pengaruh pada penurunan kadar pati resisten $(p<0,05)$. Kadar pati resisten tertinggi sebesar $7,96 \pm 0,02 \%$ sedangkan terendah sebesar $3,60 \pm 0,02 \%$. Rerata penambahan jus kubis fermentasi menurunkan kadar pati resisten dari $7,14 \pm 0,02 \%$ menjadi $4,15 \pm 0,06 \%$. Penurunan kadar pati resisten disebabkan oleh proses fermentasi yang memecah ikatan pati resisten. Hal ini mengindikasikan bahwa mikroorganisme yang terdapat pada jus kubis terfermentasi mampu memanfaatkan pati resisten sebagai prebiotik untuk mengubahnya menjadi SCFA. Bird et al. (2000) menyatakan bahwa pati resisten dapat digunakan sebagai prebiotik untuk untuk menstimulasi pertumbuhan beberapa mikrobia menguntungkan seperti Bifidobacterium karena pati resisten dapat digunakan sebagai substrat oleh organisme probiotik maupun menjaga kesehatan kolon serta memacu kecepatan produksi sel crypt. Rerata lama peram menurunkan kadar pati resisten dari 6,28 $\pm 0,03$ menjadi $5,33 \pm 0,02 \%$. Semakin lama proses fermentasi kadar pati resisten semakin menurun. Hal ini mengindikasikan bahwa kinerja mikroorganisme asal jus kubis terfermentasi sangat efisien dalam mencerna pati resisten. Penurunan kadar pati resisten sampai $5,33 \pm 0,02 \%$ mengindikasikan pati resisten perlakuan tergolong tinggi. Goni et al. (1996) mengklasifikasikan kandungan pati resisten sebagai berikut; sangat rendah $(<1 \%)$, rendah (1-2,5\%), sedang (2,5-5\%), tinggi (5-15\%) dan sangat tinggi (>15\%). Interaksi antara faktor lama peram dan penambahan jus kubis afkir terfermentasi terjadi penurunan kadar pati resisten. Interaksi ini menandakan bahwa kinerja bakteri asal jus kubis afkir terfermentasi sangat optimal dan mampu berperan sebagai sinbiotik. Nilai pati resisten terendah pada perlakuan penambahan jus kubis afkir terfermentasi sebanyak $40 \%$ dengan lama peram 4 hari sebesar $3,60 \pm 0,02 \%$. Nilai tersebut masih tergolong sedang (2,5$5 \%$ ). Sinbiotik merupakan produk fementasi yang berasal dari peningkatan kemampuan bakteri probiotik yang disebabkan oleh tersedianya substrat spesifik (prebiotik) untuk melakukan fermentasi (Figur 1) (Goni et al. 1996; Bengmark, 2001).

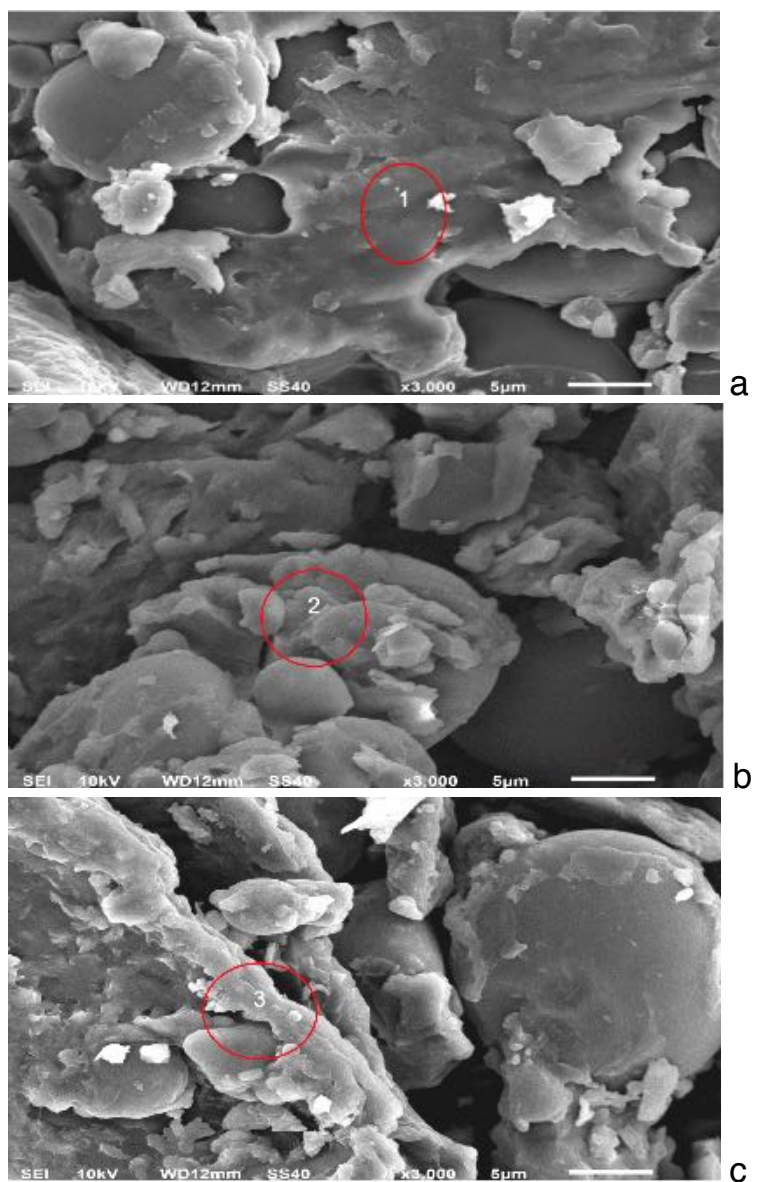

Figur 1. Scanning electron microscope (SEM) sinbiotik kultur campuran yang berasal dari bekatul gandum yang difermentasi menggunakan 0 (a), 20 (b), dan $40 \%$ (c) jus kubis terfermentasi dengan lama fermentasi 2 hari pada perbesaran 3000x. Angka dalam lingkaran mengindikasikan tampilan granula pati dan komponen serat.

\section{Analisis SEM}

Perubahan struktur bekatul gandum yang disajikan pada Figur 1 sampai 3 mencerminkan adanya perubahan struktur karbohidrat sebagai akibat dari proses pemanasan dan perombakan mikrobia hasil fermentasi. Penambahan jus kubis terfermentasi pada bekatul gandum mengakibatkan terjadinya perubahan komposisi kimia menjadi monomer sederhana sebagai hasil perombakan dari mikroorganisme yang berasal dari jus kubis terfermentasi. Jus kubis terfermentasi mengandung jenis Lactobacillus plantarum, Lactobacillus brevis, Rhizopus oryzae dan Saccharomyces cerevise yang bersifat heterofermentasi menghasilkan asam laktat dan $\mathrm{H}_{2} \mathrm{O}$ serta $\mathrm{CO}_{2}$ sebagai produk metabolit sekunder dari perombakan mikroorganisme pada bekatul gandum. Lewthwaite et al. (1997) menyatakan bahwa bakteri asam laktat dalam medium akan memfermentasi atau menghidrolisis gula menjadi komponen sederhana menjadi asam laktat, asam organik, $\mathrm{CO}_{2}, \mathrm{H}_{2} \mathrm{O}$ dan energi. Selanjutnya energi digunakan untuk sintesis sehingga terjadi kenaikan jumlah sel. Perubahan struktur bekatul gandum sinbiotik kultur campuran dapat dilihat pada Figur 1-3. Figur tersebut mencerminkan perubahan yang diakibatkan oleh mikoorganisme dari jus kubis terfermentasi. Penambahan jus kubis terfermentasi sampai level $40 \%$ memperlihatkan perubahan yang signifikan yang terlihat pada Figur 3. 


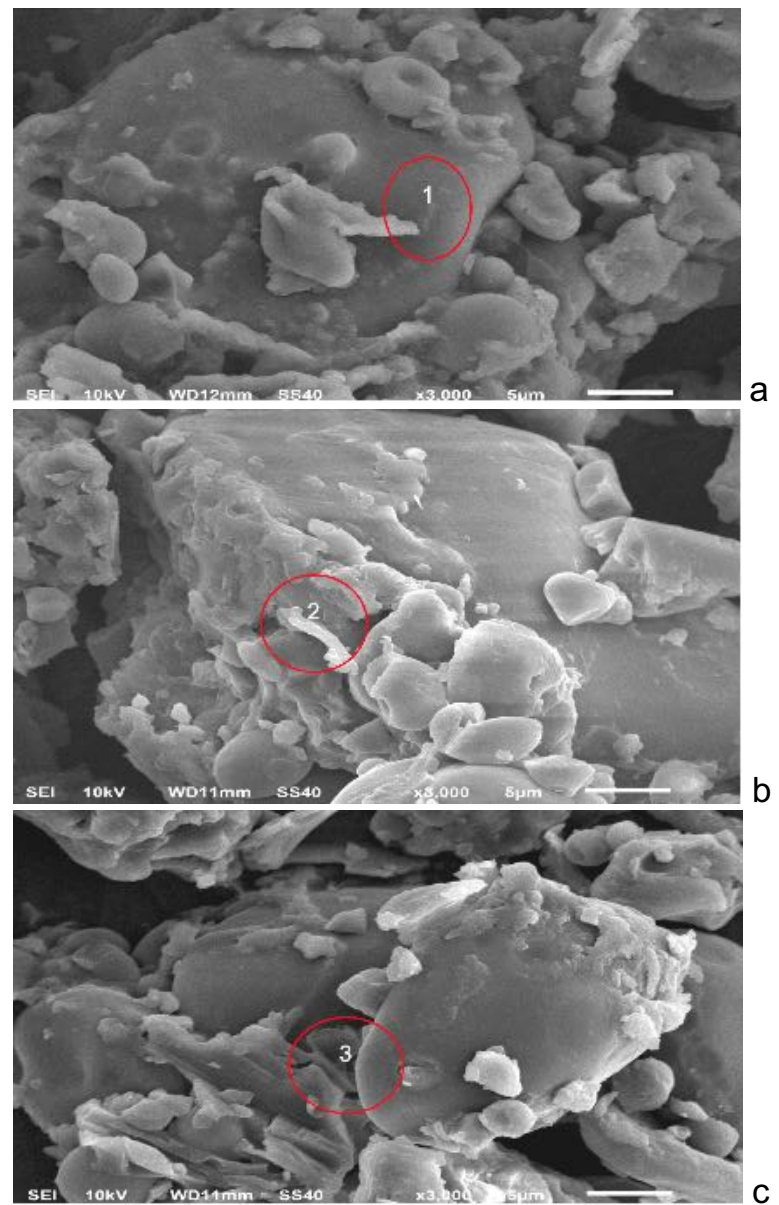

Figur 2. Scanning electron microscope (SEM) sinbiotik kultur campuran yang berasal dari bekatul gandum yang difermentasi menggunakan 0 (a), 20 (b), dan $40 \%$ (c) jus kubis terfermentasi dengan lama fermentasi 3 hari pada perbesaran 3000x. Angka dalam lingkaran mengindikasikan tampilan granula pati dan komponen serat.

Hasil terbaik dari penelitian ini yaitu perlakuan penambahan jus kubis terfermentasi sebanyak $40 \%$ dengan lama fermentasi 4 hari. Kriteria terbaik terlihat dari perubahan kandungan protein kasar, gross energi, kadar arabinosa, kadar rafinosa, kadar selulosa, hemi selulosa, lignin, pati resisten dan figur SEM bekatul gandum setelah proses fermentasi. Perubahan ini mencerminkan interaksi antara bekatul gandum sebagai prebiotik dengan jus kubis terfermentasi sebagai probiotik sehingga layak disebut sinbiotik. Kriteria sebagai sinbiotik terlihat dari penurunan kandungan oligosakarida seperti rafinosa dan penurunan pati resisten akibat pemanfaatan oleh mikrobia dari jus kubis terfermentasi. Hal ini mengindikasikan bahwa bekatul gandum dan mikoorganisme yang berada pada jus kubis terfermentasi mampu bersinergi bersama dan harapannya dapat dimanfaatkan secara efektif ketika didalam saluran pencernaan menjadi sinbiotik kultur campuran.
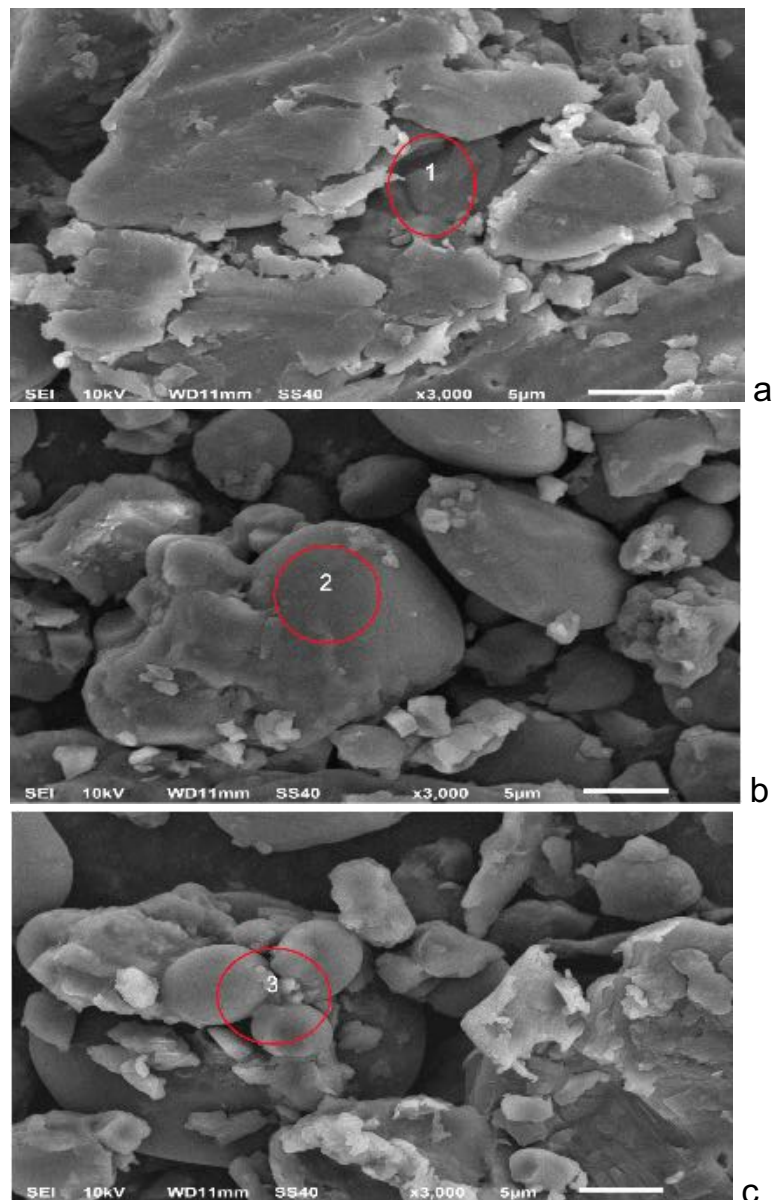

Figur 3. Scanning electron microscope (SEM) sinbiotik kultur campuran yang berasal dari bekatul gandum yang difermentasi menggunakan 0 (a), 20 (b), dan $40 \%$ (c) jus kubis terfermentasi dengan lama fermentasi 4 hari pada perbesaran 3000x. Angka dalam lingkaran mengindikasikan tampilan granula pati dan komponen serat.

\section{Kesimpulan}

Kesimpulan yang dapat diambil dari penelitian adalah pengolahan sinbiotik kultur campuran yang berasal dari kombinasi bekatul gandum sebagai prebiotik dan jus kubis terfermentasi sebagai probiotik melalui proses fermentasi didapatkan bahwa penambahan $40 \%$ jus kubis terfermentasi dengan lama pemeraman 4 hari adalah yang terbaik. Sinbiotik kultur campuran ini nantinya dapat digunakan sebagai sumber additive untuk pangan maupun kebutuhan lainnya seperti untuk pakan ternak.

\section{Daftar Pustaka}

Abdel-Raheem, S.M., Abd-Allah, S.M.S., Hassanein, K.M.A. 2012. The effects of prebiotic, probiotic and synbiotic supplementation on intestinal microbial ecology and histomorphology of broiler chickens. International Journal for Agro Veterinary and Medical Sciences 6(4):277-289. DOI:10.5455/ijavms.156.

Alloui, M.N., Szczurek, W.S., Tkiewicz, S.W. 2013. The usefulness of prebiotics and probiotics in modern poultry nutrition: Review. Annals of Animal Science 1:17-32. DOI:10.2478/v10220-0120055-x. 
Association of Official Analytical Chemists (AOAC). 2006. Official Methods of Analysis, $18^{\text {th }}$ ed. Association of Official Analytical Chemists, Washington, DC.

Baron, J.M. 1989. Friendly Bacteria. Reserved by the Roger Wyburn Mason and Jack M. Blount Foundation for Aradication of Rheumatoid Disease a.k.a The Arthritis Trust of America, US.

Bengmark, S. 2001. Pre, pro and symbiotics. Current Opinion in Clinical Nutrition and Metabolic Care 4(6): $\quad$ 571-579. $\quad$ DOI:10.1097/00075197200111000-00019.

Belitz, H.D, Grossch, W. 1999. Food Chemistry. Springer Verlag, Berlin.

Bird, A.R., Brown, I.L., Topping, D.L. 2000. Starches, resisten starches, the gut microflora and human health. Current Issues in Intestinal Microbiology 1(1):25-37. PMID:11709851.

Butt, H. 1999. Exploring management protocols for chronic fatique syndrome: a Case for pro and prebiotics. Probiotica. 8:2-6.

Carr, F., Chill, J.D., Maida, N. 2002. The lactic acid bacteria: A literature survey. Critical Reviews Microbiology. 28(4):281-370. DOI:10.1080/1040840291046759.

Charalampopoulos, D., Pandiella, S.S., Webb, C. 2002. Growth studies of potentially probiotic lactic acid bacteria in cereal - based substrates. Journal Applied Microbiology 92:851-859. DOI:10.1046/j.1365-2672.2002.01592.x.

Cherney, D.J.R. 2000. Characterization of forages by chemical analysis. In: Forage evaluation in ruminant nutrition. CABI Publishing, New York.

Collins, M.D., Gibson, G.R. 1999. Probiotics, prebiotics, and symbiotics: approaches for modulating the microbial ecology of the gut. The American Journal of Clinical Nutrition 69(5):1052S-1057S. DOI:10.1093/ajcn/69.5.1052s.

Crampton, E.W., Haris, L.E.1969. Applied Animal Nutrition. ed. 1st. The Engsminger Publishing Company, California.

Cristofaro, E., Motty, F., Wuhrmann, J.J.1994. Sugars in Nutrition. Academic Press. New York.

Eerlingen, R.C., Crombez, M., Delcour, J.A. 1993. Enzyme resisten starch I. quantitative and qualitative influence of incubation time and temperature of autoclaved starch on resisten starch pati formation. Journal Cereal Chemistry 70(3):339-344.

Fardiaz, S. 1992. Mikrobiologi Pangan. PT. Gramedia Pustaka Utama. Jakarta

Giraud, G.R., Williams, C.M. 2000. Funtional Foods, Concept to Product. CRC Press, New York.

Goering, H.K., Van Soest, P.J. 1970. Forage Fiber Analysis. Agriculture Handbook No. 379. ARS USDA, Washington DC.

Goni, I.,G Diz, L., Manas, E., Calixto, F.S. 1996. Analysis of resistant starch: a method for foods and food products. Journal of Food Chemistry 56 (4):445449. DOI: 10.1016/0308-8146(95)00222-7.
Hardy, H., Harris, J., Lyon, E., Beal, J., Foey, A. D. 2013. Probiotics, prebiotics and immunomodulation of gut mucosal defences: homeostasis and immunopathology. Nutrients. 5(6):1869-1912. DOI:10.3390/nu5061869

Hartadi, H., Reksohadiprodjo, S., Tilman, A. D.1997. Tabel komposisi bahan pakan untuk Indonesia. Gadjah Mada University Press, Yogyakarta.

Hodge, J. E., Osman, E. M.1976. Carbohydrate. Di dalam: Fennema, O.R. (ed.). Principles of food sciences. Marcel Dekker. Inc., New York.

Huang, D. P., Rooney, L.W.2001. Starches for snacks foods. Dalam Lusas, R.W., Rooney, L.W. (eds). 2001. Snack foods processing. CRC Press. New York.

Hustiany, R. 2006. Modifikasi asilasi dan suksinilasi pati tapioka sebagai bahan enkapsulasi komponen flavor. Disertasi, Institut Pertanian Bogor. Bogor.

Irma, S. R, Zubaida, E., Saparianti, E.2015. Evaluasi Pertumbuhan Isolat Probiotik ( $L$. casei dan $L$. plantarum) dalam medium fermentasi berbasis ubi jalar (Ipomoea batatas L.) selama proses fermentasi (kajian jenis isolat dan jenis tepung ubi jalar). Jurnal Aplikasi Teknologi Pangan 4(4):133141. DOI: 10.17728/jatp.v4i4.3.

Jung, G.H.J. 1997. Analysis of forage fiber and cell walls in ruminant nutrition. Journal of Nutrition 127:810813. DOI:10.1093/jn/127.5.810S

Kearsly, M.W. 1988. Physical, Chemical and Biochemical Methods of Analysis of Carbohidrates. Analysis of Food Carbohydrates. Elsevier Applied Science Publisher Ltd., England.

Khalid, M.N., Elmer, H.M. 2008. Proteolytic activity by strains L. plantarum and L. casei. Journal of Dairy Science 73:3068-3076. DOI:10.3168/jds.S00220302(90)78994-1.

Krabi, R.E, Assamoi, A.A., Ehon, F.A., Niamke. 2015. Screening of lactic acid bacteria as potential starter for the production of attieke, a fermented cassava food. Food and Environment Safety Journal 14(1):21-29.

Lewthwaite, S.L, Sutton, K.H., Triggs, C.M. 1997. Free sugar composition of sweet potato cultivars after storage. New Zealand Journal of Crop and Horticultural Science 25:33-41. DOI:10.1080/ 01140671.1997 .9513984$.

Li, X., Liu, L.Q., Xu, C.L. 2008. Effects of supplementation of fructo-oligosaccharide and/or Bacillus subtilis to diets on performance and intestinal microflora in broilers. Archiv für Tierzucht 51: 64-70. DOI:10.5194/aab-51-642008.

Lu, C.D, Kawas, J.R., Maghoub, O.G. 2005. Fiber digestion and utilization in goats. Small Ruminant Research 60:45-65. DOI: 10.1016/j.smallrumres. 2005.06.035.

Markowiak, P., Sli'zewska, K. 2017. Effects of probiotics, prebiotics, and synbiotics on human health. Nutrients 9(9):1021. DOI:10.3390/nu9091021.

Marsono, Y. 1999. Perubahan kadar resisten starch (RS) dan komposisi kimia beberapa bahan pangan 
kaya karbohidrat dalam proses pengolahan. Agritech 9(3):124-127. DOI:10.22146/agritech. 13729.

Miller, T.L., Wolin, J.M. 1996. Pathways of acetate, propionate, and butyrate formation by the human fecal microbial flora. Applied and Environmental Microbiology 62(5):1589 -1592. DOI:10.1128/ AEM.62.5.1589-1592.

Mookiah, S., Sieo, C.C., Ramasamy, K., Abdullah, N., Ho, Y.W. 2014. Effects of dietary prebiotics, probiotic and symbiotic on performance, caecal bacterial populations and caecal fermentation concentrations of broiler chickens. Journal of Science Food Agriculture 94(2): 341-348. DOI:10.1002/jsfa.6365.

Murarolli, V.D.A., Burbarelli, M.F.C., Polycarpo, G.V., Ribeiro, P.A.P., Moro, M.E.G., Albuquerque, R. 2014. Prebiotic, probiotic and symbiotic as alternative to antibiotics on the performance and immune response of broiler chickens. Brazilian Journal of Poultry Science 16(3):279-284. DOI: 10.1590/1516-635x1603279-284.

Narasimha, G. Sridevi, A., Buddolla, V., Subhosh, C.M., Rajasekhar, R.D. 2006. Nutrient effects on productions of cellulolytic enzymes by Aspergillus niger. African Journal of Biotechnology 5:472-476.

National Research Council (NRC). 2001. Nutrient Requirement of Dairy Cattle. 7thed. National Academy Press, Washington, D.C.

Oberman, H. 1985. Fermented milks. In Microbiology of Fermented Foods. Vol. 1 Edited by J.B. Wood. Elsevier Appl. Sci. Publ., New York.

Pandey, K.R., Naik, S.R., Vakil, B.V.2015. Probiotics, prebiotics and synbiotics- a review. Journal of Food Science and Technology 52:7577-7587. DOI:10.1007/s13197-015-1921-1.

Preston, T.R., Leng, R.A. 1987. Matching Ruminant Production System with Available Resources in the Tropics and Sub-tropics. Penambul Books, Australia.

Rackis, J.J. 1989. Physiological Effects of Food Carbohydrates. American Chemical Society, Washington D.C.

Ryan, S.M., Fitzgerald, G.F., Sinderen, D. 2006. Screening for and identification of starch,amylopectin-, and pullulan-degrading activities in Bifidobacterial strains. Appl Environ Microbiol. 2006 Aug; 72(8): 5289-5296. DOI: 10.1128/AEM.00257-06.

Sajilata, M.G, Rekha, S.S., Kulkarni, P.R. 2006. Resisten starch $-A$ review. Comprehensive reviews in food science and food safety 5(1):1-17. DOI:10.1111/j.1541-4337.2006.tb00076.x.

Salminen, S., Wright, A.V.1993. Lactic Acid Bacteria: Microbiology and Functional Aspects. Marcel Dekker Inc., New York.

Sebayang, F. 2006. Pembuatan etanol dari molases secara fermentasi menggunakan sel Saccharomyces cerevisiae yang terimobilisasi pada kalsium alginat. Jurnal Teknologi Proses 5(2):75 - 80
Steel, R.G.D., Torrie, J.H.1993. Prinsip dan prosedur statistik suatu pendekatan biometrik. Diterjemahkan oleh Bambang Sumantri. Cetakan ke- 4. Gramedia Pustaka Utama, Jakarta.

Sudarmadji, S., Haryono, B., Suhardi. 1984. Prosedur Analisa untuk Bahan Makanan dan Pertanian. Liberty, Yogyakarta.

Taggart, P. 2004. Starch as an Ingredients: Manufacture and Applications. In Ann Charlotte Eliasson (ed). Starch in Food: Structure, Function, and Applications. CRC Press, Florida.

Utama, C.S., Sulistiyanto, B., Kismiati, S. 2017. The effects of water addition and steaming duration on starch composition of wheatpollard. Reaktor 17(4):220-224. DOI:10.14710/reaktor.17.4.221225.

Utama, C.S., Zuprizal, Hanim, C., Wihandoyo. 2018a. Probiotic testing of Lactobacillus brevis and Lactobacillus plantarum from fermented cabbage waste juice. Pakistan Journal of Nutrition 17(7):323-328. DOI:10.3923/pjn.2018.323.328.

Utama, C.S., Zuprizal, Hanim, C., Wihandoyo.2018b. Isolasi dan identifikasi bakteri asam laktat selulolitik yang berasal dari jus kubis terfermentasi. Jurnal Aplikasi Teknologi Pangan 7(1):1-6. DOI:10.17728/jatp.2155.

Utama, C.S., Zuprizal, Hanim, C., Wihandoyo. 2019. Pengaruh lama pemanasan terhadap kualitas kimia wheat pollard yang berpotensi sebagai prebiotik. Jurnal Aplikasi Teknologi Pangan 8(3):113-123. DOI:10.17728/jatp.5262.

Van Soest, P.J., Robertson, J.B., Lewis, B.A. 1991. Methods for dietary fiber, neutral detergent fiber and non-starch polysaccharides in relation to animal nutrition. Journal of Dairy Science 74:3583-3597. DOI:10.3168/jds.S0022-0302(91) 78551-2.

Wahyu J. 1994. IImu Nutrisi Unggas. Penerbit Gadjah Mada University Press. Yogyakarta.

Walter, H.G., Kohler, G.O. 1981. Treated and untreated cellulosic wastes as animal feeds: Recent work in the United States of America. Agriculture and Environment 6(2):229-243. DOI:10.1016/03041131(81)90013-8.

Wigyanto, Suharjono, Novita. 2001. Pengaruh konsentrasi gula reduksi sari hati nanas dan inokulum Saccharomyces cerevisiae pada fermentasi etanol. Jurnal Teknologi Pertanian 2 (1):68-77.

Wurzburg, O. B. 1989. Modified starches. properties and uses. CRC Press, 5 Boca Raton, Florida.

Yoon, K.Y, Edward, E.W., Yong, D.H. 2004. Probiotication of tomato juice by lactic acid bacteria. Journal of Microbiology 42(4):315-318.

Zubaidah, E., Saparianti, E., Hindrawan, J. 2012. Studi aktivitas antioksidan pada bekatul dan susu skim terfermentasi probiotik Lactobacillus plantarum B2 dan Lactobacillus acidophilus. Jurnal Teknologi Pertanian 3(2):111-118. 